\title{
Impact of preoperative glycometabolic status on outcomes in cardiac surgery: Systematic review and meta-analysis
}

Claudio Corazzari, MD, ${ }^{\mathrm{a}, \mathrm{b}}$ Matteo Matteucci, MD, ${ }^{\mathrm{a}, \mathrm{b}}$ Michalina Kołodziejczak, MD,, $\mathrm{d}$

Mariusz Kowalewski, MD, ${ }^{\mathrm{a}, \mathrm{e}, \mathrm{f}}$ Anna Maria Formenti, MD, ${ }^{\mathrm{g}}$ Andrea Giustina, MD, ${ }^{\mathrm{g}}$ Cesare Beghi, MD, ${ }^{\mathrm{b}}$

Fabio Barili, MD, PhD, MStat, ${ }^{\mathrm{h}}$ and Roberto Lorusso, MD, $\mathrm{PhD},{ }^{\mathrm{a}, \mathrm{i}}$

\section{ABSTRACT}

Background: Historically, impaired glucose metabolism has been associated with early and late complicated clinical outcomes after cardiac surgery; however, such a condition is not specific to subjects with diabetes mellitus and involves a larger patient population.

Methods: Databases were screened (January 2000 to December 2020) to identify eligible articles; studies that evaluated the association between preoperative metabolic status, as assessed by glycosylated hemoglobin levels and clinical outcomes, were considered. The studies were stratified in thresholds by baseline glycosylated hemoglobin level (lower vs higher).

Results: Thirty studies, involving 34,650 patients, were included in the review. In a meta-analysis stratified by glycosylated hemoglobin levels, early mortality was numerically reduced in each threshold comparison and yielded the highest reductions when less than $5.5 \%$ versus greater than $5.5 \%$ glycosylated hemoglobin levels were compared (risk ratio, 0.39; 95\% confidence interval, 0.18-0.84; $P=.02$ ). Comparing higher glycosylated hemoglobin threshold values yielded comparable results. Late mortality was reduced with lower levels of glycosylated hemoglobin. Low preoperative glycosylated hemoglobin was associated with the lowest risk of sternal wound infections (risk ratio, 0.50; 95\% confidence interval, 0.32-0.80; $P=.003$ and risk ratio, $0.53 ; 95 \%$ confidence interval, 0.39-0.70; $P<.0001$ ) for comparisons of less than $7.5 \%$ versus greater than $7.5 \%$ and less than $7.0 \%$ versus greater than $7.0 \%$ glycosylated hemoglobin thresholds, respectively. Additionally, levels of glycosylated hemoglobin lower than $7 \%$ were associated with reduced hospital stay, lower risk of stroke/transient ischemic attack (risk ratio $0.53 ; 95 \%$ confidence interval, 0.39-0.70; $P<.0001$ ), and acute kidney injury (risk ratio, 0.65; 95\% confidence interval, 0.54-0.79; $P<.0001$ ).

Conclusions: Lower levels of glycosylated hemoglobin in patients undergoing cardiac surgery are associated with a lower risk of early and late mortality, as well as in the incidence of postoperative acute kidney injury, neurologic complications, and wound infection, compared with higher levels. (J Thorac Cardiovasc Surg 2022;164:1950-60)

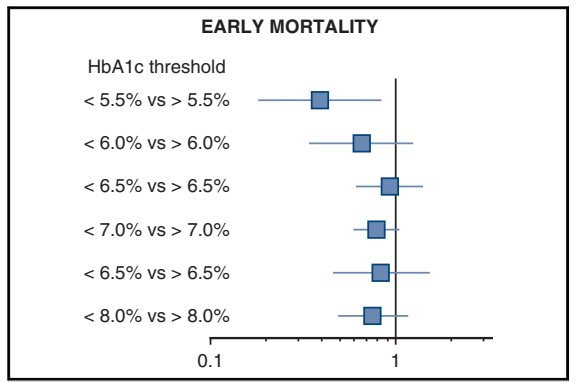

Reduction of risk for early mortality in patients with preoperative optimal glycemic control.

CENTRAL MESSAGE

A J-shaped relationship exists between lower values of preoperative HbA1c and lower risk of early and late mortality after surgery, as well as in the incidence of preoperative AKI, stroke/TIA, and sternal wound infection.

\section{PERSPECTIVE}

This meta-analysis of 30 studies, including approximately 35,000 patients, found that compared with lower thresholds of $\mathrm{HbA}_{1 \mathrm{c}}$, higher preoperative $\mathrm{HbA} 1 \mathrm{c}$ levels were associated with an increased risk of postoperative mortality and morbidity in patients who underwent cardiac surgery. Therefore, intensive $\mathrm{HbA} 1 \mathrm{c}$ lowering is advisable to reduce the operative risk for worse outcomes.

See Commentaries on pages 1961 and 1963.
From the a'Department of Cardiothoracic Surgery, Heart and Vascular Centre, Maastricht University Medical Centre, Maastricht, the Netherlands; ${ }^{b}$ Department of Surgical and Morphological Sciences, Circolo Hospital, University of Insubria, Varese, Italy; ${ }^{\mathrm{c}}$ Department of Anaesthesiology and Intensive Care, Collegium Medicum Nicolaus Copernicus University, Antoni Jurasz University Hospital No. 1, Bydgoszcz, Poland; ${ }^{\mathrm{d}}$ Yale Cardiovascular Research Group, Yale School of Medicine, New Haven, Conn; ${ }^{\mathrm{e}}$ Department of Cardiac Surgery, Central Clinical Hospital of the Ministry of Interior, Centre of Postgraduate Medical Education,

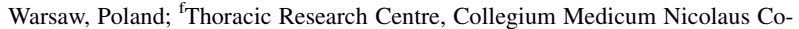
pernicus University, Innovative Medical Forum, Bydgoszcz, Poland; ' ${ }^{g}$ Institute of Endocrine and Metabolic Sciences, San Raffaele Vita-Salute University, IRCCS San Raffaele Hospital, Milan, Italy; ${ }^{\text {h}}$ Cardiac Surgery Unit, S. Croce Hospital, Cuneo, Italy; and ${ }^{\mathrm{i} C a r d i o v a s c u l a r}$ Research Institute Maastricht (CARIM), Maastricht University, Maastricht, the Netherlands.
Prospero ID: CRD42020160942.

Drs Corazzari and Matteucci contributed equally to this work.

Received for publication Aug 17, 2020; revisions received April 21, 2021; accepted for publication May 13, 2021; available ahead of print June 1, 2021.

Address for reprints: Matteo Matteucci, MD, Cardiothoracic Surgery Department, Heart \& Vascular Centre, Maastricht University Medical Centre, P. Debyelaan, 12_6221 AZ Maastricht, The Netherlands (E-mail: matteomatteucci87@ gmail.com).

0022-5223

Copyright (C) 2021 The Authors. Published by Elsevier Inc. on behalf of The American Association for Thoracic Surgery. This is an open access article under the CC BY license (http://creativecommons.org/licenses/by/4.0/).

https://doi.org/10.1016/j.jtcvs.2021.05.035 

Abbreviations and Acronyms
AKI = acute kidney injury
$\mathrm{CABG}=$ coronary artery bypass grafting
$\mathrm{CI}=$ confidence interval
$\mathrm{DM}=$ diabetes mellitus
HbA1c $=$ glycosylated hemoglobin
$\mathrm{MD}=$ mean difference
MI = myocardial infarction
$\mathrm{RR}=$ risk ratio
TIA $=$ transient ischemic attack

\begin{abstract}
Scanning this QR code will take
you to the table of contents to access supplementary information.
\end{abstract}

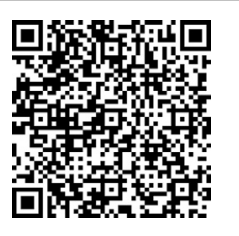

Diabetes mellitus (DM) is one of the most challenging concerns for public health. According to the latest 2016 data from the World Health Organization, an estimated 422 million of adults are affected by DM. ${ }^{1}$ Patients with DM have a 2- to 4-fold increase in the risk of developing cardiovascular disease than those without DM and a 2- to 5-fold increased mortality due to cardiovascular disease when compared with age- and sex-matched persons without DM. ${ }^{2}$

Patients with DM represent approximately $25 \%$ of subjects undergoing coronary revascularization, ${ }^{3}$ and coronary artery bypass grafting $(\mathrm{CABG})$ is the preferred method of revascularization for this subgroup of patients in the presence of multivessel coronary disease. ${ }^{4-7}$ Previous studies have clearly demonstrated that high perioperative blood glucose levels are associated with an increased incidence of postoperative complications and reduced survival after CABG. ${ }^{8,9}$ Yet, hyperglycemia on random serum samples does not necessarily reflect the long-term status of glycometabolic control being potentially influenced by several concomitant factors, including underlying diseases and related treatments leading to hospitalization. ${ }^{10}$ Hyperglycemia has been reported to act as a strong predictor of both morbidity and mortality in subjects without a previous diagnosis of DM undergoing cardiac surgery. ${ }^{11}$ An adjunctive potentially confounding factor may be underdiagnosis and consequent underestimation of DM in the general population. ${ }^{12}$

Measuring glycosylated hemoglobin (HbAlc) levels preoperatively is the method of choice for defining glycometabolic status because it reflects blood glucose levels of the 2 to 3 months before the assessment. ${ }^{13}$ The American Diabetes Association currently advocates that diabetic subjects should achieve target $\mathrm{HbAlc}$ levels less than $7 \%$ because it is associated with a lower risk of diabetes-related complications. ${ }^{13}$
Several studies have evaluated the potential clinical implications of $\mathrm{HbA} 1 \mathrm{c}$ levels in diabetic and nondiabetic patients undergoing cardiac surgery. However, most of these studies were retrospective in design, with no adequate statistical power, due to the relatively small sample size, to draw definitive conclusions. Therefore, we performed a systematic review and meta-analysis of the existing literature to evaluate whether baseline preoperative glycometabolic status, as assessed by serum HbA1c levels, is associated with the early and long-term cardiac surgery outcomes reductions.

\section{MATERIALS AND METHODS}

This systematic review and meta-analysis were conducted in accordance to the Preferred Reporting Items for Systematic Review and Meta-Analysis guidelines $^{14}$ and registered in PROSPERO (International Prospective Register of Systematic Reviews) (ID: CRD42020160942). The need for ethical approval and consent was waived for this systematic review.

\section{Search Strategy and Data Extraction}

MEDLINE, EMBASE, and the Cochrane Central Register of Controlled Trials were searched for eligible studies from January 1, 2000, to December 31, 2020. Keywords pertinent to the exposure of interest were used in relevant combinations: "cardiac surgery," "open-heart surgery," "hyperglycemia," "glycemic control," "glucose variability," "glycated hemoglobin," "glycosylated hemoglobin." The literature search was limited to articles published in English. Reference lists were reviewed manually and crosschecked for other relevant reports.

Randomized controlled trials, prospective, and retrospective observational cohort studies that compared clinical outcomes in patients undergoing cardiac surgery based on preoperative glycometabolic control, as assessed by glycated hemoglobin $(\mathrm{HbAlc})$ thresholds, were included in our analysis.

Studies were excluded if they met one of the following exclusion criteria: (1) pediatric (age <18 years) and congenital heart surgeryrelated studies; (2) reviews or case reports; (3) nonhuman studies; (4) studies or arms in which HbAlc levels could not be ascertained or was reported as continuous variable; (5) studies not reporting the clinical outcomes of interest. In case of multiple publications on the same patient cohort and institution, the most complete study in terms of outcome and patient information was selected for reporting, unless providing, separately, long-term follow-up.

Titles, abstracts, and full-text articles were independently reviewed by 2 investigators (C.C. and M.M.) against the specified inclusion criteria. Discrepancies were resolved through consensus and consultation with a third investigator (R.L.). Two reviewers (C.C. and M.M.) extracted data from the selected studies by using a standardized form, and a third investigator (R.L.) checked the collected data for completeness and accuracy.

\section{Outcome Measures and Quality Assessment}

The primary outcome of this meta-analysis was early mortality, defined as any death, regardless of cause, occurring in-hospital or within 30 days after surgery; death occurring after 30 days during was only considered if during the index hospitalization subsequent to the surgery. Secondary outcomes included postoperative complications: acute kidney injury (AKI), sternal wound infection, cerebrovascular events inclusive of stroke or transient ischemic attack (TIA), and myocardial infarction (MI). Outcome definitions were adopted as for the included studies. Additionally, we meta-analyzed the postoperative length of hospital stay and late ( $>1$ year) mortality.

The quality assessment of included studies has been performed in accordance with the recommendations given by the Cochrane Prognosis Methods Group for evaluating risk of bias in prognostic factor studies; thus, risk of bias at the individual study level was assessed using the Quality In Prognosis Studies tool. ${ }^{15,16}$ 


\section{Statistical Analysis}

Statistical analysis was performed using Review Manager version 5.3.5 (The Nordic Cochrane Centre, Copenhagen, Denmark) and Comprehensive Meta-Analysis 2.2 (Biostat, Englewood, NJ). The Cochran's Q test and $I^{2}$ test were performed to judge the heterogeneity among the studies included in the meta-analysis. Heterogeneity was also considered to be significant at $P$ less than .10 for the Q statistic. An $I^{2}$ value less $40 \%$ indicates low heterogeneity, values between $40 \%$ and $70 \%$ suggest moderate heterogeneity, and $I^{2}$ greater than $70 \%$ were considered high heterogeneity. To best account for within- and between studies variance, pooled analyses were performed by the random-effects model. Studies reporting outcomes of interest were included in subgroups representing thresholds of preoperative glycometabolic control: (1) HbA1c less than $5.5 \%$ versus more than $5.5 \%$; (2) less than $6.0 \%$ versus more than $6.0 \%$; (3) less than $6.5 \%$ versus more than $6.5 \%$; (4) less than $7.0 \%$ versus more than $7.0 \%$; (5) less than $7.5 \%$ versus more than $7.5 \%$; and (6) less than $8.0 \%$ versus more than $8.0 \%$. The data were assigned to specific thresholds based on the stratification applied in the original study. Pooled risk ratios (RRs) were reported with $95 \%$ confidence intervals (CIs) for each subgroup. For the analysis of length of hospital stay, mean difference (MD) along with $95 \%$ CIs is reported. Whenever applicable, median and interquartile ranges were converted to mean \pm standard deviation according to Wan and colleagues. ${ }^{17}$ RRs per person-years accounting for potential differences in follow-up are reported for the more than 1 year mortality again for each threshold comparison. Publication bias was examined by the visual assessment of funnel plots ${ }^{18}$ and by Egger's regression. Additionally, by means of meta-regression, we addressed potential relationships between early mortality and baseline characteristics by counter-opposing available baseline characteristics versus log mortality RR, across different thresholds of $\mathrm{HbA1c}$; and given single study arms' HbA1c thresholds versus logit mortality event rate. Study arms reporting " 0 events" in both compared HbA1c thresholds were not considered for a subgroup meta-analysis. Single arms reporting " 0 events" were not considered for meta-regression.

\section{RESULTS}

\section{Study Selection and Participants}

The Preferred Reporting Items for Systematic Review and Meta-Analysis flow diagram describing the study selection along with the reasons for exclusion is presented in Figure E1. After removal of reports not pertinent to the design of the current review, 30 observational studies that met inclusion criteria remained, ${ }^{19-25, \mathrm{E} 1-\mathrm{E} 23}$ including a total of 34,650 patients. The selected articles were published between 2008 and 2020, and the number of patients for each trial ranged from 72 to 6415 . Engoren and colleagues ${ }^{\mathrm{E} 24}$ report longterm outcomes in a separate report. Of 30 studies, 21 compared 2 thresholds and 9 reported on more subgroups.

Tables E1 and E2 summarize the main characteristics and outcomes of the included studies. The mean age of the patients was $63.2 \pm 3.2$ years, and approximately $60 \%$ of cases had preoperative history of DM. CABG was the surgical procedure most frequently performed $(94.9 \%)$, followed by valve surgery $(3.3 \%)$. A summary of the risk of biases of included trial is reported in Table E3. Overall, quality assessment indicated no low-quality study.

\section{Early Mortality}

All 30 studies contributed to the analysis of early mortality. Visual inspection of the funnel plot for the primary end point showed a symmetrical distribution indicating no evidence of publication bias, and this was confirmed in Egger's test (Figure E2). Overall early mortality was $1.9 \%$ $(656 / 34,650)$ (Table E2). The direction of the estimates in each glycemic level comparison subgroup favored lower $\mathrm{HbA1c}$ level, which reached significance in the subgroup comparing less than $5.5 \%$ versus more than $5.5 \%$, with $1.06 \%$ (23/2177 patients) and 2.05\% (102/4973 patients) corresponding early mortality rates (RR, $0.39,95 \% \mathrm{CI}$, $0.18-0.84, P=.02$, heterogeneity $P=.24, \mathrm{I}^{2}=29 \%$ ) (Figure 1). A "J-shaped" relationship was found between $\log$ RR of early mortality and HbA1c successive thresholds (Figure 2) (exponential function $=$ coefficient $6.91 \mathrm{CIs}$ [6.69-7.14], $P<.001)$. The trend of reduction was present in the subgroup comparing less than $7.0 \%$ versus more than $7.0 \%$, with $1.57 \%(248 / 15,644$ patients $)$ and $2.26 \%$ (209/9267 patients) dying in an early postoperative period (RR, $0.79,95 \%$ CI $, 0.59-1.05, P=.10$, heterogeneity $P=.09, \mathrm{I}^{2}=31 \%$ ). Meta-regression analysis performed counter-opposing RR of early mortality against baseline characteristics of patients in the included studies (age, gender, diabetes, heart failure) in each threshold did not show the RR, being significantly influenced by variability of these characteristics in single studies. A trend toward lesser benefit with $\mathrm{HbA} 1 \mathrm{c}$ less than $7.5 \%$ and $\mathrm{HbA} 1 \mathrm{c}$ less than $8.0 \%$ was seen with increasing number of patients with a history of heart failure (Table E4). Restricting the analysis to the patients undergoing CABG (eg, excluding 2 studies $^{\mathrm{E} 7, \mathrm{E} 23}$ conducted in the setting of valve surgery exclusively) did not change the direction or magnitude of the estimates. As a further sensitivity analysis, a metaregression of single study arms' HbA1c thresholds versus logit mortality event rate was performed; there was a significant linear relationship with lower baseline HbA1c levels and lower mortality rates (Bcoefficient $=-1.175 ; P=.025$ ).

\section{Late Mortality}

Eight studies $19,23, \mathrm{E} 4, \mathrm{E} 6, \mathrm{E} 11, \mathrm{E} 13, \mathrm{E} 15, \mathrm{E} 24$ with 15,464 patients provided late mortality data. Mean (weighted) follow-up was $3.9 \pm 1.4$ years (range, 1.0-5.5 years) (Table E2). A lower $\mathrm{HbA1c}$ level resulted in reduced late mortality in every glycometabolic level comparison subgroup: less than $5.5 \%$ versus more than $5.5 \%$ ( $-44 \%$ rate reduction, $P=.09), 6.0 \%$ versus more than $6.0 \%(-45 \%$ rate reduction, $P=.07)$, less than $6.5 \%$ versus more than $6.5 \%(-41 \%$ rate reduction, $P=.01)$, less than $7.0 \%$ versus more than $7.0 \%(-26 \%$ rate reduction, $P=.01$ ), less than $7.5 \%$ versus more than $7.5 \%$ ( $-25 \%$ rate reduction, $P=.01)$, less than $8.0 \%$ versus more than $8.0 \%(-22 \%$ rate reduction, $P=.003)$ (Figure 3$)$.

\section{Sternal Wound Infection}

A total of 22 studies $^{19-25, E 1-E 3, E 5, E 7-E 16, E 22 ~ e n r o l l i n g ~}$ 25,843 patients contributed to the analysis of sternal wound infections. The highest HbA1c subgroup comparisons were associated with the highest benefit of lower glycometabolic 


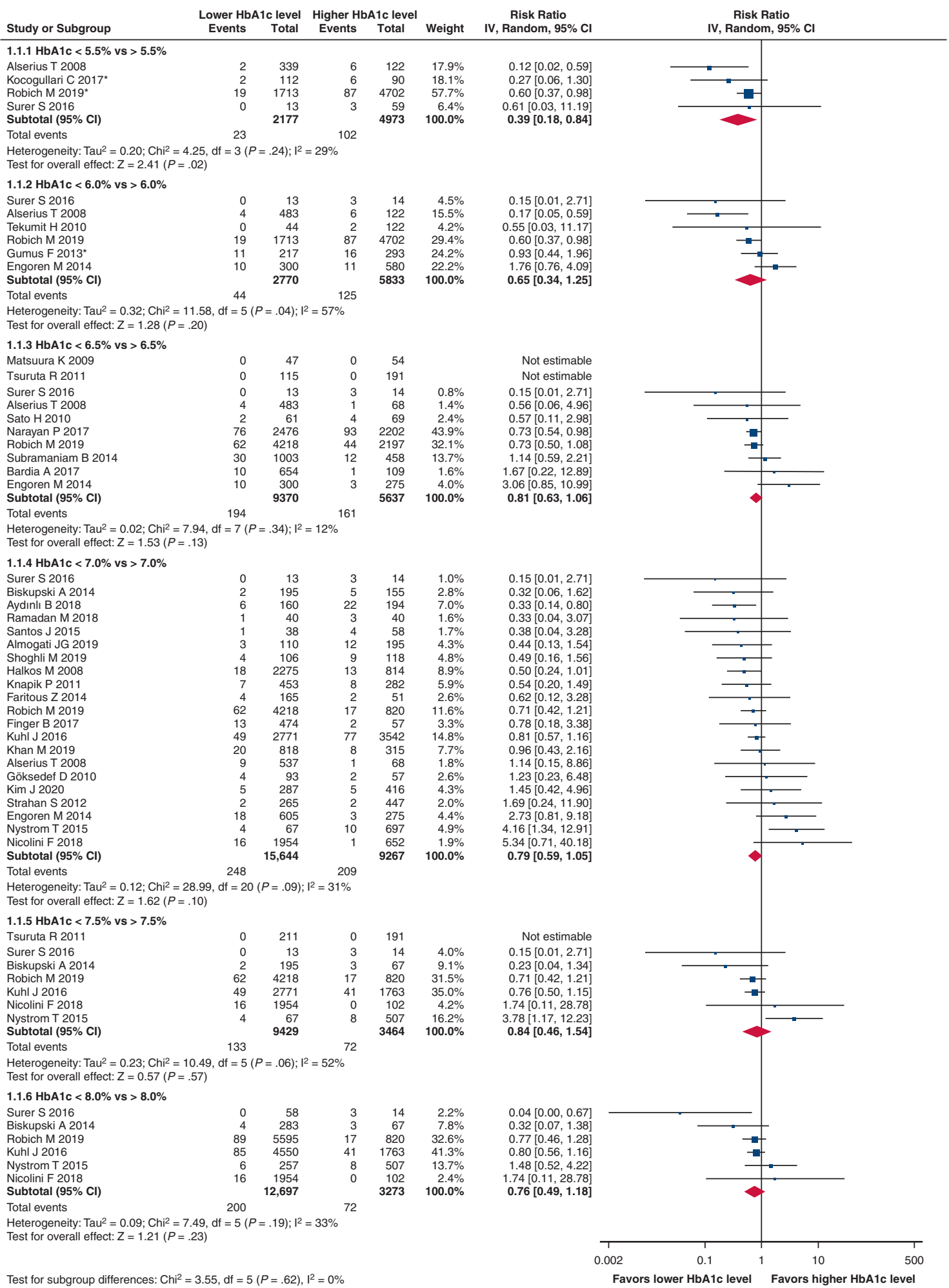

FIGURE 1. Stratified meta-analysis of lower versus higher HbAlc levels for the analysis of primary end point: early mortality. RRs are reported for each study and pooled within the respective subgroup. Size of a square corresponds to statistical weight of a study; red diamonds are indicative of effect estimate. $H b A 1 c$, Glycosylated hemoglobin; $I V$, inverse variance; $C I$, confidence interval. *Study was included in the threshold following approximation of achieved HbA1c level: Kocogullar1 C 2017: HbA1c 5.6\% instead of 5.5\%; Robich M 2019: HbA1c 5.7\% instead of 5.5\%; Gumus F 2013: HbA1c 5.9\% instead of $6.0 \%$. 


\section{EARLY MORTALITY}

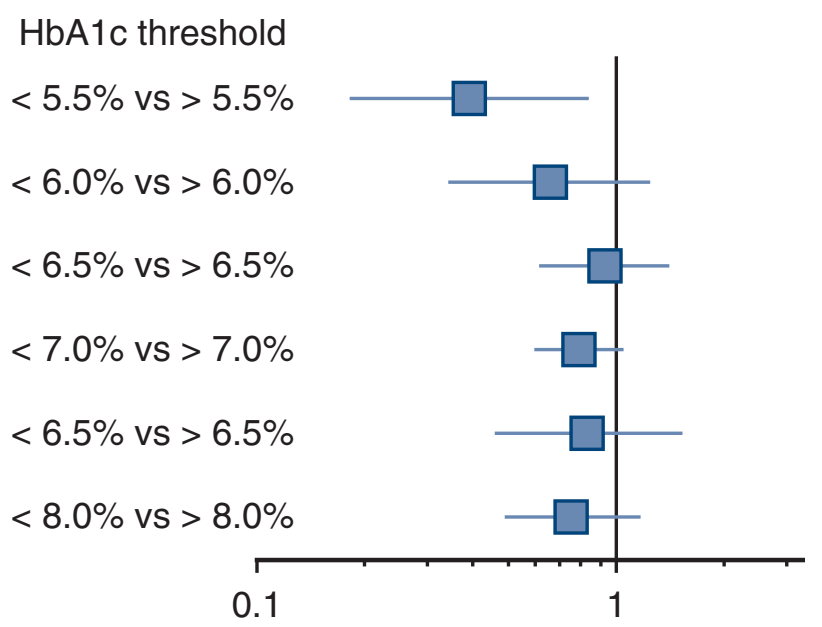

FIGURE 2. Reduction of risk for early mortality in patients with preoperative optimal glycemic control. $H b A l c$, Glycosylated hemoglobin.

level comparator, with a risk reduction of $-77 \%(P<.0001$, $<8.0 \%$ vs $>8.0 \%),-78 \%(P<.001,<7.5 \%$ vs $>7.5 \%)$, $-63 \% \quad(P<.0001, \quad<7.0 \%$ vs $>7.0 \%), \quad-52 \%$ $(P<.0001,<6.5 \%$ vs $>6.5 \%),-53 \%(P=.02,6.0 \%$ vs $>6.0 \%$ ) (Figure 4).

\section{Stroke/Transient Ischemic Attack}

A total of 19 studies $^{20-25, E 1, E 3, E 5, E 7-E 15, E 18}$ with 24,451 patients provided data for the stroke/TIA analysis. Two subgroups, less than $7.0 \%$ versus more than $7.0 \%$ (RR, 0.53 , 95\% CI, 0.39-0.70, $P<.0001$, heterogeneity $P=.78$, $\left.\mathrm{I}^{2}=0 \%\right)$ and less than $7.5 \%$ versus more than $7.5 \%(\mathrm{RR}$, $0.50,95 \%$ CI, $0.32-0.80, P=.003$, heterogeneity $P=.67$, $\mathrm{I}^{2}=0 \%$ ), yielded the highest stroke/TIA. The statistically significant stroke/TIA reduction in the lower HbA1c group was also present in all remaining comparisons: less than $6.5 \%$ versus more than $6.5 \%$ (RR, 0.72, 95\% CI, 0.53-0.97, $P=.03$, heterogeneity $P=.36, \mathrm{I}^{2}=9 \%$ ) and less than $8.0 \%$ versus more than $8.0 \%$ (RR, $0.56,95 \% \mathrm{CI}, 0.36-$ $0.87, P=.01$, heterogeneity $P=.84, \mathrm{I}^{2}=0 \%$ ) (Figure 5).

\section{Acute Kidney Injury}

A total of 21 studies $^{20-25, E 1-E 3, E 5, E 7-E 15, E 18, E 20 ~ w i t h ~ 24,869 ~}$ patients provided data for the AKI analysis. The direction of the estimates in each glycemic level comparison subgroup favored lower HbA1c level, which reached a trend of reduction in the subgroup comparing less than $6.0 \%$ versus more than $6.0 \%$ (RR, $0.46,95 \%$ CI, $0.18-1.15, P=.10$, heterogeneity $P=.005, \mathrm{I}^{2}=81 \%$ ). The subgroup less than $7.0 \%$ versus more than $7.0 \%$ yielded the lower AKI rate (RR, $0.65,95 \%$ CI, 0.54-0.79, $P<.0001$, heterogeneity $P=.10, \mathrm{I}^{2}=35 \%$ ). The statistically significant AKI reduction in the lower HbA1c group was also present in all remaining comparison thresholds: less than $6.5 \%$ versus more than
$6.5 \%$ (RR, 0.77, 95\% CI, 0.71-0.84, $P<.0001$, heterogeneity $P=.58, \mathrm{I}^{2}=0 \%$ ), less than $7.5 \%$ versus more than $7.5 \%$ (RR, 0.73, 95\% CI, 0.65-0.82, $P<.0001$, heterogeneity $P=.74, \mathrm{I}^{2}=0 \%$ ), and less than $8.0 \%$ versus more than $8.0 \%$ (RR, 0.76, 95\% CI, 0.68-0.85, $P<.0001$, heterogeneity $P=.60, \mathrm{I}^{2}=0 \%$ ) (Figure 6$)$.

\section{Myocardial Infarction}

Thirteen studies ${ }^{19,20,22-25, E 1-E 3, E 5, E 7, E 11, E 18}$ with 9803 patients reported MI data. There were no statistically significant differences between lower and higher values of HbA1c in terms of MI (Figure E3), although there was a numeric reduction in the number of MIs in the subgroup comparison less than $7.0 \%$ versus more than $7.0 \%: 1.59 \%$ (64/4036) versus $2.21 \%$ (47/2122) (RR, 0.71, 95\% CI, 0.44-1.15, $P=.17$, heterogeneity $P=.30, \mathrm{I}^{2}=16 \%$ ).

\section{Hospital Length of Stay}

Thirteen studies ${ }^{19-22,24,25, E 8, E 11, E 14-E 16, E 21, E 23 ~ w i t h ~} 8092$ patients contributed to the analysis of length of hospital stay, which was estimated at $9.5 \pm 4.1$ days in the entire cohort (Table E2). Lower levels of HbA1c were associated with a significantly reduced length of stay: MD $-0.61(95 \% \mathrm{CI}$, -1.23 to $-0.00, P=.05$, heterogeneity $P=.45 ; \mathrm{I}^{2}=0 \%$ ) in $6.0 \%$ versus more than $6.0 \%, \mathrm{MD}-0.92(95 \% \mathrm{CI}$, $-1.69,-0.15, P=.02$, heterogeneity $P=.50 ; \mathrm{I}^{2}=0 \%$ ) in less than $6.5 \%$ versus more than $6.5 \%$, MD $-0.81(95 \%$ CI, $-1.11,-0.51, P<.0001$, heterogeneity $P=.32$; $\mathrm{I}^{2}=14 \%$ ) in less than $7.0 \%$ versus more than $7.0 \%$ (Figure E4).

\section{DISCUSSION}

The incidence of insulin resistance and DM continues to increase and remains a tremendous threat to public health. ${ }^{1}$ However, increased random blood glucose levels are not specific to diabetic subjects. Hyperglycemia may be encountered in surgical and critically ill nondiabetic patients. ${ }^{\text {E25 }}$ Multiple daily glucose measurements or continuous blood glucose monitoring can give more reliable information on the glycometabolic status but are not applicable to a general population. ${ }^{10}$ In addition to glucose measurements, a variety of different approaches have been proposed over time to evaluate and monitoring glycometabolic status. ${ }^{\mathrm{E} 6} \mathrm{HbA1c}$ values reflect the 2- to 3-month average endogenous exposure to glucose, including postprandial spikes in the blood glucose, and have low intraindividual variability, particularly in persons without DM. ${ }^{\text {E27 }}$ Therefore, HbAlc is currently thought to be a solid marker of the long-term glycometabolic status both in patients with and without DM. ${ }^{13}$

Limited numbers of studies have investigated the relationship between preoperative glycemic control, assessed by glycated hemoglobin (HbA1c) levels, and surgical outcomes in patients undergoing cardiac operation. The current 


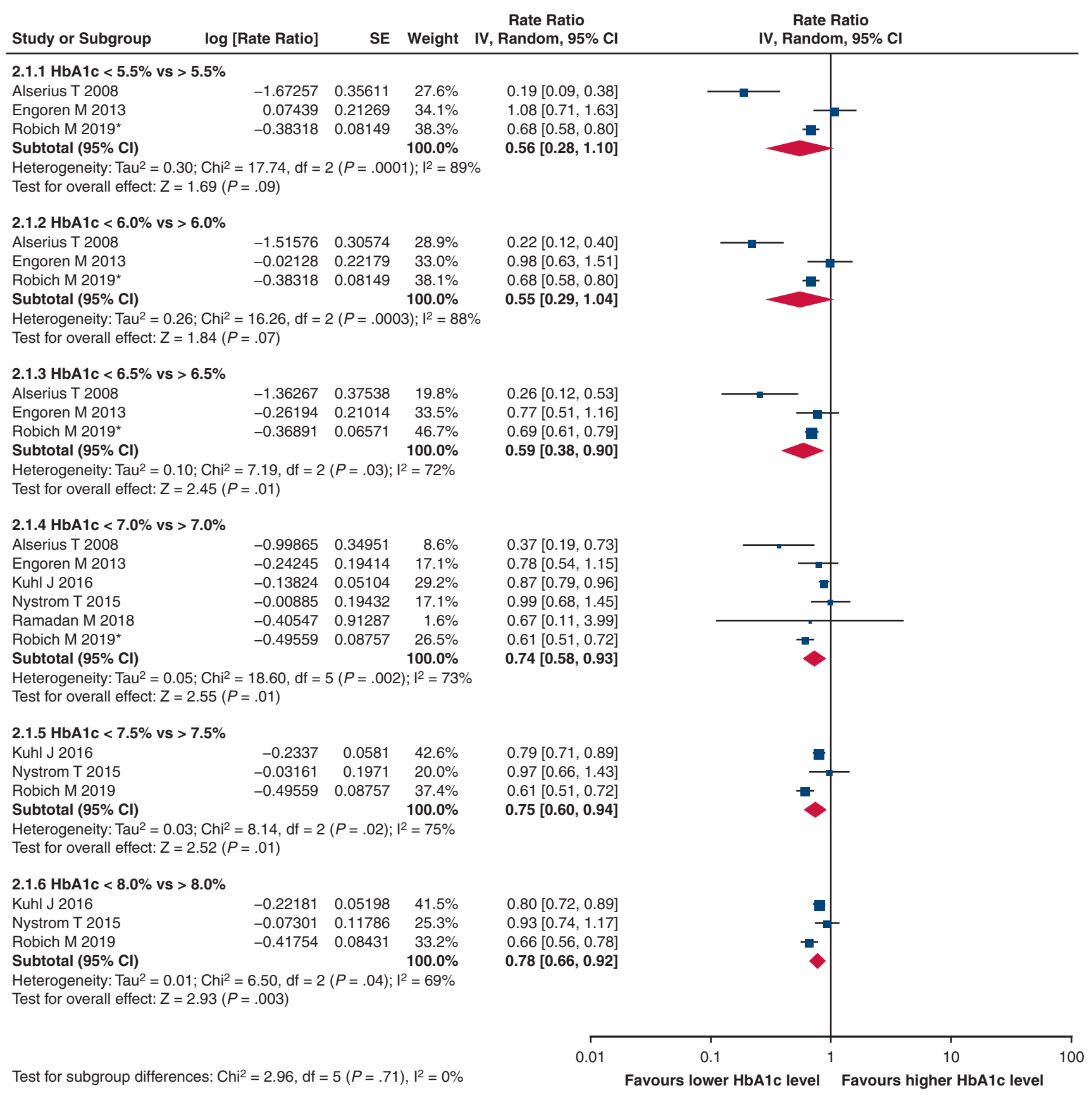

FIGURE 3. Stratified meta-analysis of lower versus higher HbA1c levels for the analysis of late mortality. RRs per person-years are reported for each study and pooled within the respective subgroup. Remaining information as in legend to Figure 1. SE, Standard error; $I V$, inverse variance; $C I$, confidence interval; HbAlc, glycosylated hemoglobin.

meta-analysis aimed to highlight the prognostic significance of preoperative glycometabolic status on long-term outcome in subjects undergoing a wide range of cardiac surgery procedures.

Our study provides a notable insight into the association between preoperative $\mathrm{HbA} 1 \mathrm{c}$ level and morbidity, as well as mortality of patients undergoing cardiac surgeries. The degree of glycometabolic control affected the overall survival even in the early 30-day period. The highest benefit of the early mortality reduction was observed in the less than
$5.0 \%$ versus more than $5.0 \% \mathrm{HbA} 1 \mathrm{c}$ level. Likewise, the late mortality had the lowest prevalence within the lowest HbA1c level comparison, which, driven by a higher number of events observed over longer period of time, reached statistical significance in every analyzed threshold, as resembled by the J-shaped mortality curve. To our knowledge, this is the first report to present results of even slightly elevated $\mathrm{HbA1c}$ levels, a nonprocedure-specific variable, that may affect a hard clinical outcome such as mortality at short-term follow-up. 


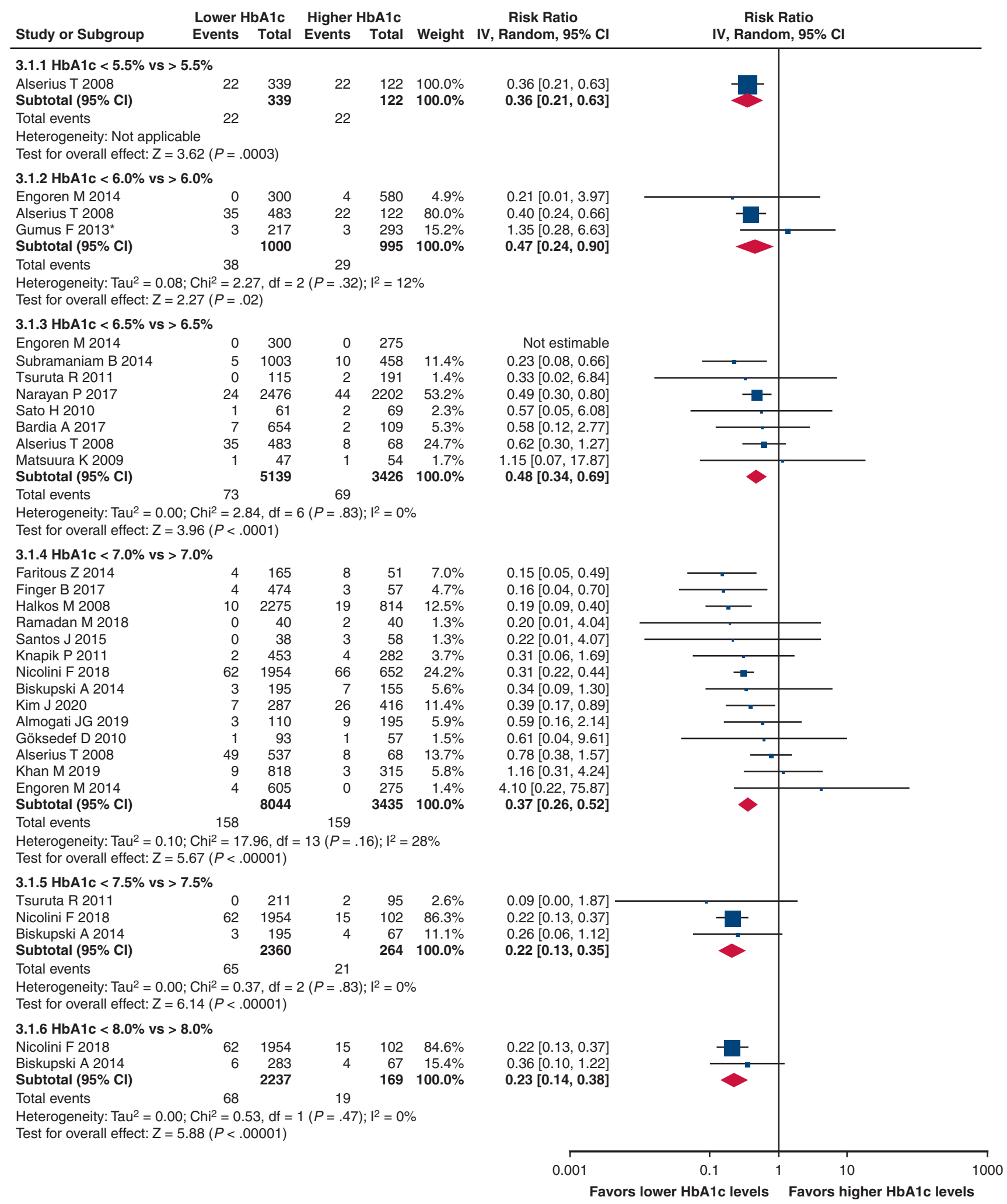

FIGURE 4. Stratified meta-analysis of lower versus higher HbAlc levels for the analysis of sternal wound infection. RRs are reported for each study and pooled within the respective subgroup. Remaining information as in legend to Figure 1. HbAlc, Glycosylated hemoglobin; $I V$, inverse variance; $C I$, confidence interval.

Independently of diabetic status, perioperative elevated levels of blood glucose have been linked with increases in morbidity and mortality, and prolonged hospitalization after surgery. ${ }^{\text {E28 }}$ Hyperglycemia-induced oxidative stress induces endothelial dysfunction that plays a central role in the pathogenesis of tissue and organ damage. ${ }^{\mathrm{E} 29}$ Trials 


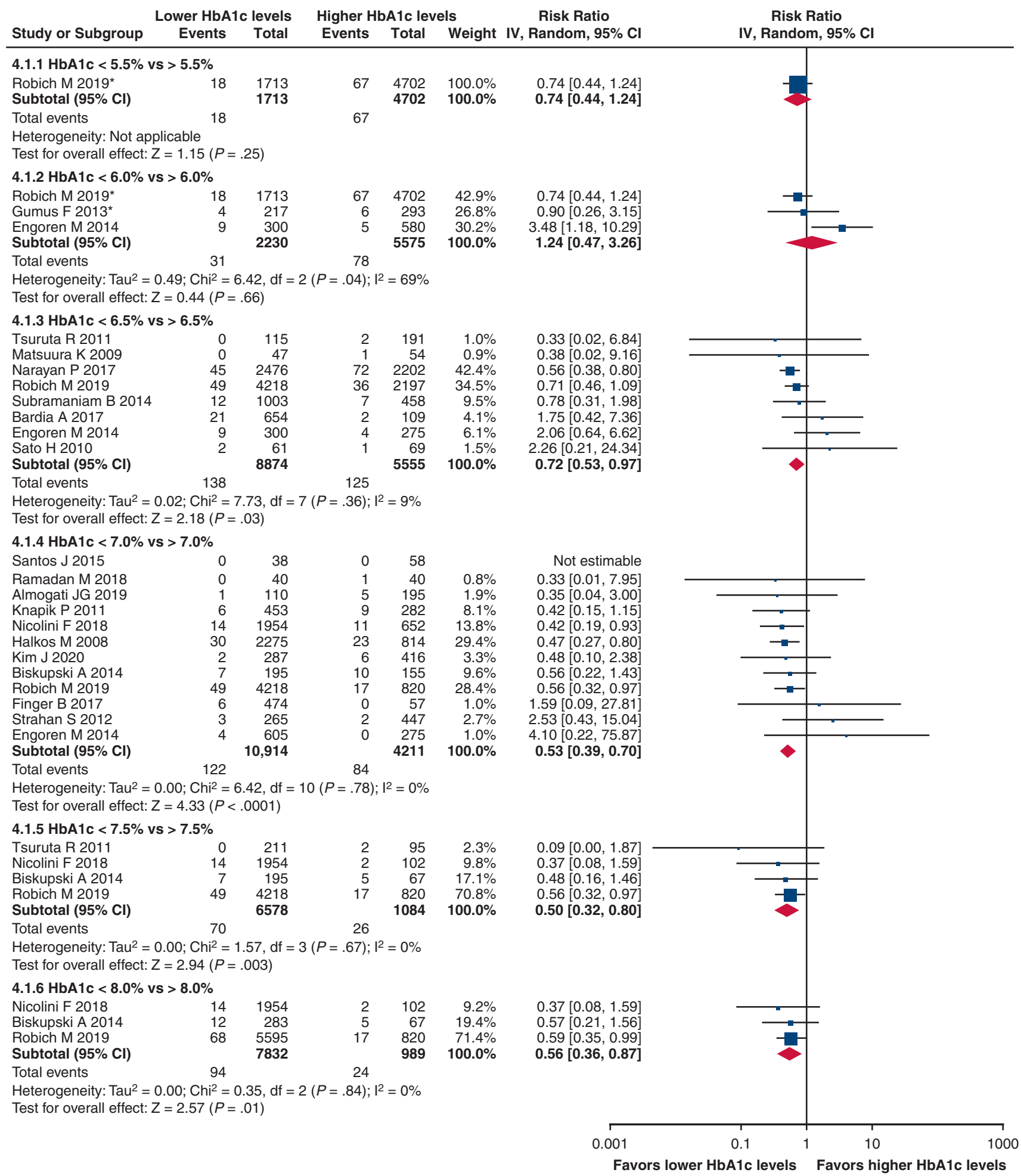

FIGURE 5. Stratified meta-analysis of lower versus higher HbAlc levels for the analysis of stroke or TIA. RRs are reported for each study and pooled within the respective subgroup. Remaining information as in legend to Figure 1. HbAlc, Glycosylated hemoglobin; $I V$, inverse variance; $C I$, confidence interval.

have clearly demonstrated that the risk of cardiovascular events and deaths can be reduced by intensive glucose control. ${ }^{11, \mathrm{E} 30}$ Our findings suggest that altered relatively longterm glycometabolic status, regardless of a preexisting diagnosis of DM, is associated with an increased risk of postoperative mortality, AKI, neurologic complications, wound infection, and prolonged hospital length of stay in patients undergoing cardiac surgery. 


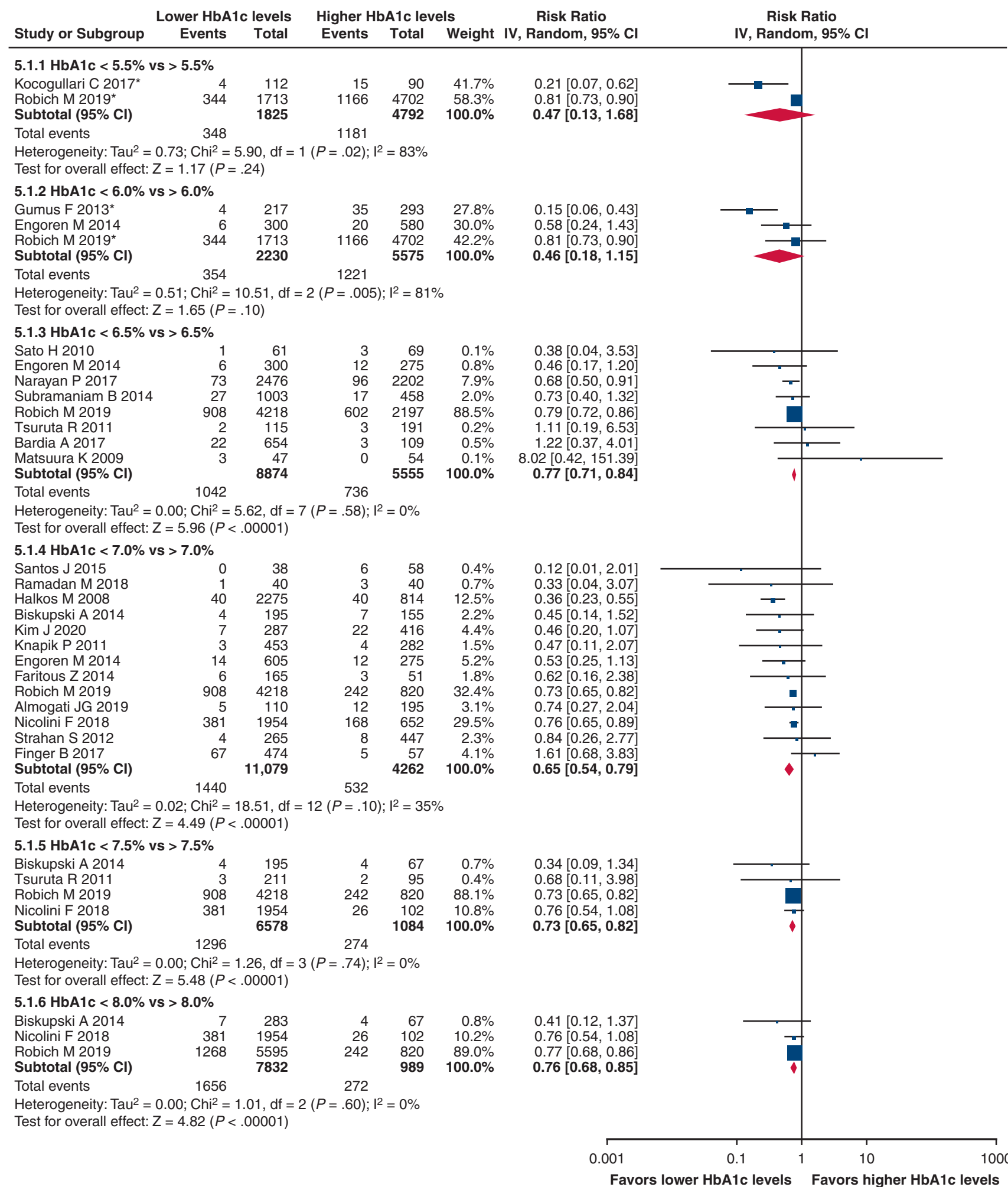

FIGURE 6. Stratified meta-analysis of lower versus higher HbA1c levels for the analysis of AKI. RRs are reported for each study and pooled within the respective subgroup. Remaining information as in legend to Figure 1. HbAlc, Glycosylated hemoglobin; $I V$, inverse variance; $C I$, confidence interval.

The highest rate of stroke/TIA and AKI was found in the threshold comparing $7.0 \%$ versus more than $7.0 \%$ of $\mathrm{HbA} 1 \mathrm{c}$, with $35 \%$ and circa $50 \%$ rate reduction in patients with lower glycemic level. Those results are in line with the recommendations of the American Diabetes Association emphasizing the need of achieving $\mathrm{HbAlc}$ levels less than $7 \%$, for the reduction of diabetic-specific outcomes. Although the general association between wound infection 
and diabetes is well established, and confirmed by our report, cerebrovascular outcomes are not specific for diabetic patients in cardiac surgery. Those findings emphasize the need to optimize hypoglycemic treatment for a long period of time before elective cardiac surgery to lower the risk of clinical end points, as well as the hospitalization length, which ultimately would translate to a total reduction in the treatment costs.

Although the association between $\mathrm{HbAlc}$ levels and perioperative MI was not statistically significant, a trend toward a higher risk of MI with higher HbA1c levels was observed, which is in accordance with a previous report. ${ }^{\mathrm{E} 2}$ The results of the current study were consistent with those of current systematic reviews, namely, the preoperative $\mathrm{HbA} 1 \mathrm{c}$ level had a statistically significant effect on the incidence of mortality in diabetic patients after cardiac surgery. ${ }^{\mathrm{E} 1}$ However, a recent meta-analysis showed contrasting results, ${ }^{\text {E32 }}$ mainly because the authors included the percutaneous coronary intervention studies and the follow-up time for postoperative mortality varied greatly (ranging from before discharge to 7 years after surgery). Moreover, Wang and colleagues $^{\mathrm{E} 32}$ focused only on elective CABG surgery, ignoring the other cardiac surgical procedures.

The exact mechanisms underlying the correlation between higher $\mathrm{HbA} 1 \mathrm{c}$ concentrations and worse clinical outcomes have not been adequately elucidated. Our results can be explained in several ways. First, higher HbAlc levels are commonly associated with metabolic syndrome whose components (obesity, dyslipidemias, hypertension, insulin resistance) increase the risk of worse surgical outcome. ${ }^{\mathrm{E} 31, \mathrm{E} 33}$ Second, chronic hyperglycemia contributes to oxidative stress and endothelial damage, which can ultimately lead to organ dysfunction. ${ }^{\text {E29 }}$

An increasing number of patients with a history of DM are presenting for valve surgery; thus, the effect of this disease on outcomes becomes important when discussing surgical options. Previous studies have indicated that DM had a negative impact on survival in patients undergoing valve replacement, particularly with regard to bioprosthesis. ${ }^{\mathrm{E} 34, \mathrm{E} 35}$ On this basis, stricter glycemic control might be advisable in adults undergoing tissue valve implantation who have an exceedingly high risk of structural valve degeneration, such as diabetic and dialyzed subjects. However, because most reports included in the current review analyzed patients referred to CABG, a general conclusion cannot be drawn from this study. Therefore, whether adequate glucose control improved surgical outcomes in diabetic and nondiabetic adults undergoing valve operation must be demonstrated in dedicated prospective trials.

DM represents a significant toll on health budgets around the world, accounting for $5 \%$ to $20 \%$ of total healthcare expenditure in many countries. ${ }^{\mathrm{E} 36}$ Both absolute costs and proportion of overall health budget for DM are set to increase in the future decades as prevalence increases; therefore, cost-effective treatment and prevention strategies will become increasingly important as resources become stretched. ${ }^{\mathrm{E} 37}$ Preoperatively identifying an abnormally high $\mathrm{HbA} 1 \mathrm{c}$ in patients with DM or prediabetes or not yet diagnosed diabetes helps direct attention to optimize glycemic control in patients with elevated HbAlc levels to minimizing the subsequent incidence of postoperative complications and reducing the costs of health care. ${ }^{\mathrm{E} 38}$

In contrast to preoperative impaired glycometabolic status, the impact of postoperative abnormal or appropriate glycemic control is unknown. Few studies have addressed such issues, although persistent hyperglycemic metabolic syndrome is expected to exert substantial influence on several aspects of postoperative surgical results, ranging from revascularization recurrence or tissue valve degeneration, endocarditis, or other adverse events. It is uncertain how a well-compensated or not well-compensated metabolic syndrome may affect patient well-being, implanted device or prosthetic function/integrity, or progression of the underlying disease. These aspects should represent a critical target for future investigation to assess the association between enhanced and optimal DM control versus long-term adverse event rates.

\section{Study Limitations}

Although the results from this meta-analysis raise the possibility that preoperative optimal glycometabolic status may confer some benefit to subjects undergoing cardiac surgery, there are a number of limitations that should be considered in the interpretation of our results. First, most of the included studies have a retrospective nature. Retrospective studies are subject to confounders and bias, possibly affecting the conclusive power of this metaanalysis. Second, critical information, such as type of $\mathrm{DM}$, ejection fraction, coronary artery disease, timing of surgery, and comorbidities, which are potential confounders, was not reported in several studies, and this may limit the effect size of our findings. Third, we acknowledge the important methodological differences between studies: The varying proportion of diabetic and nondiabetic subjects may add to heterogeneity observed within single studies, in particular between less than $6.5 \%$ versus more than $6.5 \%$ and less than $7.0 \%$ versus more than $7.0 \%$ of $\mathrm{HbA} 1 \mathrm{c}$ levels because these were cutoff values for DM diagnosis in some studies. On the other hand, inclusion by design both diabetic and nondiabetic populations confers the benefit of including patients with newly diagnosed $\mathrm{DM}$ in whom the effect of HbA1c lowering may be less pronounced. Last, we lacked information regarding the specific cause of death; therefore, only all-cause mortality was considered and investigated in the present meta-analysis.

\section{CONCLUSIONS}

The results of this study indicate that preoperative $\mathrm{HbAlc}$ levels may play an important role in the prognosis of 
diabetic and nondiabetic patients undergoing cardiac surgery. Our meta-analysis, despite expected diversity for different outcomes likely due to its all-inclusive nature, suggests that $\mathrm{HbA} 1 \mathrm{c}$ levels represent a continuous risk, ranging between $5.5 \%$ and $7.0 \%$, with some variation in risk profiles at different levels of HbA1c. In particular, lower levels of preoperative $\mathrm{HbAlc}$ were associated with a lower risk of early and late mortality, as well as in the incidence of postoperative AKI, neurologic complications, and wound infection, compared with higher levels. Because preoperative HbA1c levels may universally predict possible high glucose-related complications of cardiac surgery, with lower values related to the better outcomes, it seems justified to recommend that all patients should undergo before the operation an $\mathrm{HbA1c}$ assay and a periodical control of metabolic compensation after surgery. Specifically, those patients with known diabetes should undergo cardiac surgery only after obtaining normalization or near normalization of $\mathrm{HbAlc}$ levels through optimization of their management. Moreover, the finding of not normal $(>5.5 . \%)$ HbAlc levels in patients without a previous diagnosis of diabetes should prompt a presurgical metabolic workup to put in place adequate measures to obtain its normalization before the operation and during the follow-up.

\section{Conflict of Interest Statement}

The authors reported no conflicts of interest.

The Journal policy requires editors and reviewers to disclose conflicts of interest and to decline handling or reviewing manuscripts for which they may have a conflict of interest. The editors and reviewers of this article have no conflicts of interest.

The authors thank Maria Velasco and Eugenio Massa for their valuable contribution.

\section{References}

1. World Health Organization. Global report on diabetes. Geneva, Switzerland: WHO; 2016. Working Papers ID 10553.

2. American Diabetes Association. Diabetes statistics. Available at: http://www. Diabetes.Org/diabetes-basics/diabetes-statistics/. Accessed April 1, 2020.

3. Flaherty JD, Davidson CJ. Diabetes and coronary revascularization. JAMA. 2005; 293:1501-8.

4. Hillis LD, Smith PK, Anderson JL, Bittl JA, Bridges CR, Byrne JG, et al. 2011 ACCF/AHA guideline for coronary artery bypass graft surgery: a report of the American College of Cardiology Foundation/American Heart Association task force on practice guidelines. Circulation. 2011;124:e652-735.

5. Cosentino F, Grant PJ, Aboyans V, Bailey CJ, Ceriello A, Delgado V, et al; ESC Scientific Document Group. 2019 ESC Guidelines on diabetes, pre-diabetes, and cardiovascular diseases developed in collaboration with the EASD. Eur Heart J. 2020;41:255-323.

6. Lorusso R, Pentiricci S, Raddino R, Scarabelli TM, Zambelli C, Villanacci V, et al. Influence of type 2 diabetes on functional and structural properties of coronary artery bypass conduits. Diabetes. 2003;52:2814-20.
7. Lorusso R, De Cicco G, Beghi C, Gherli T, Poli E, Corradi D, et al. Functional effects of nitric oxide-releasing aspirin on vein conduits of diabetic patients undergoing CABG. Int J Cardiol. 2007;118:164-9.

8. Lazar HL, Chipkin SR, Fitzgerald CA, Bao Y, Cabral H, Apstein CS. Tight glycemic control in diabetic coronary artery bypass graft patients improves perioperative outcomes and decreases recurrent ischemic events. Circulation. 2004; 109:1497-502.

9. Ouattara A, Lecomte P, Le Manach Y, Landi M, Jacqueminet S, Platonov I, et al Poor intraoperative blood glucose control is associated with a worsened hospital outcome after cardiac surgery in diabetic patients. Anesthesiology. 2005;103: 687-94.

10. Misra A, Bloomgarden ZT. Discordance between HbA1c and glycemia. J Diabetes. 2018;10:908-10.

11. Ascione R, Rogers CA, Rajakaruna C, Angelini GD. Inadequate blood glucose control is associated with in-hospital mortality and morbidity in diabetic and nondiabetic patients undergoing cardiac surgery. Circulation. 2008;118:113-23.

12. Meijnikman AS, De Block CE, Verrijken A, Mertens I, Corthouts B, Van Gaal LF. Screening for type 2 diabetes mellitus in overweight and obese subjects made easy by the FINDRISC score. J Diabetes Complications. 2016;30:1043-9.

13. American Diabetes Association. 6. Glycemic targets: standards of medical care in diabetes-2019. Diabetes Care. 2019;42(Suppl 1):S61-70.

14. Moher D, Liberati A, Tetzlaff J, Altman DG, PRISMA Group. Preferred reporting items for systematic reviews and meta-analyses: the PRISMA statement. $J$ Clin Epidemiol. 2009;62:1006-12.

15. Riley RD, Moons KGM, Snell KIE, Ensor J, Hooft L, Altman DG, et al. A guide to systematic review and meta-analysis of prognostic factor studies. BMJ. 2019; $364: \mathrm{k} 4597$.

16. Hayden JA, van der Windt DA, Cartwright JL, Côté P, Bombardier C. Assessing bias in studies of prognostic factors. Ann Intern Med. 2013;158:280-6.

17. Wan X, Wang W, Liu J, Tong T. Estimating the sample mean and standard deviation from the sample size, median, range and/or interquartile range. BMC Med Res Methodol. 2014;14:135.

18. Sterne JAC, Egger M, Moher D. Addressing reporting biases. In: Higgins JPT, Green S, eds. Cochrane Handbook for Systematic Reviews of Interventions. Version 5.1.0. Chichester, UK: John Wiley \& Sons; 2017.

19. Alserius T, Anderson RE, Hammar N, Nordqvist T, Ivert T. Elevated glycosylated haemoglobin $(\mathrm{HbA} 1 \mathrm{c})$ is a risk marker in coronary artery bypass surgery. Scand Cardiovasc J. 2008;42:392-8.

20. Halkos ME, Puskas JD, Lattouf OM, Kilgo P, Kerendi F, Song HK, et al. Elevated preoperative hemoglobin A1c level is predictive of adverse events after coronary artery bypass surgery. J Thorac Cardiovasc Surg. 2008;136: 631-40.

21. Sato H, Carvalho G, Sato T, Lattermann R, Matsukawa T, Schricker T. The association of preoperative glycemic control, intraoperative insulin sensitivity, and outcomes after cardiac surgery. J Clin Endocrinol Metab. 2010;95: 4338-44.

22. Knapik P, Cieśla D, Filipiak K, Knapik M, Zembala M. Prevalence and clinical significance of elevated preoperative glycosylated hemoglobin in diabetic patients scheduled for coronary artery surgery. Eur J Cardiothorac Surg. 2011; 39:484-9.

23. Tsuruta R, Miyauchi K, Yamamoto T, Dohi S, Tambara K, Dohi T, et al. Effect of preoperative hemoglobin A1c levels on long-term outcomes for diabetic patients after off-pump coronary artery bypass grafting. J Cardiol. 2011;57: $181-6$.

24. Engoren M, Schwann TA, Habib RH. Elevated hemoglobin Alc is associated with readmission but not complications. Asian Cardiovasc Thorac Ann. 2014; 22:800-6.

25. Gumus F, Polat A, Sinikoglu SN, Yektas A, Erkalp K, Alagol A. Use of a lower cut-off value for $\mathrm{HbA} 1 \mathrm{c}$ to predict postoperative renal complication risk in patients undergoing coronary artery bypass grafting. J Cardiothorac Vasc Anesth. $2013 ; 27: 1167-73$.

Key Words: cardiac surgery, coronary artery bypass grafting, diabetes mellitus, glycosylated hemoglobin 


\section{E-References}

E1. Biskupski A, Waligórski S, Kowalik B, Żych A, Sielicki P, Mirecki O, et al. Glycated hemoglobin $\mathrm{HbA} 1 \mathrm{c}-\mathrm{a}$ new risk marker for the outcome of cardiac surgery? Kardiochir Torakochirurgia Pol. 2014;11:7-11.

E2. Faritous Z, Ardeshiri M, Yazdanian F, Jalali A, Totonchi Z, Azarfarin R. Hyperglycemia or high hemoglobin A1C: which one is more associated with morbidity and mortality after coronary artery bypass graft surgery? Ann Thorac Cardiovasc Surg. 2014;20:223-8.

E3. Subramaniam B, Lerner A, Novack V, Khabbaz K, Paryente-Wiesmann M, Hess P, Talmor D. Increased glycemic variability in patients with elevated preoperative $\mathrm{HbA} 1 \mathrm{C}$ predicts adverse outcomes following coronary artery bypass grafting surgery. Anesth Analg. 2014;118:277-87.

E4. Nyström T, Holzmann MJ, Eliasson B, Kuhl J, Sartipy U. Glycemic control in type 1 diabetes and long-term risk of cardiovascular events or death after coronary artery bypass grafting. J Am Coll Cardiol. 2015;66:535-43.

E5. Santos JM, Favaloro RR, Lowenstein D, Sanabria H, Raffaelli H, Hershson A. Medium-term glycemic control in diabetics before coronary bypass surgery. Medicina (B Aires). 2015;75:277-81.

E6. Kuhl J, Sartipy U, Eliasson B, Nyström T, Holzmann MJ. Relationship between preoperative hemoglobin A1c levels and long-term mortality after coronary artery bypass grafting in patients with type 2 diabetes mellitus. Int J Cardiol. 2016;202:291-6

E7. Bardia A, Khabbaz K, Mueller A, Mathur P, Novack V, Talmor D, Subramaniam B. The association between preoperative hemoglobin A1C and postoperative glycemic variability on 30-day major adverse outcomes following isolated cardiac valvular surgery. Anesth Analg. 2017;124:16-22.

E8. Finger B, Brase J, He J, Gibson WJ, Wirtz K, Flynn BC. Elevated hemoglobin Alc is associated with lower socioeconomic position and increased postoperative infections and longer hospital stay after cardiac surgical procedures. Ann Thorac Surg. 2017; 103:145-51.

E9. Narayan P, Kshirsagar SN, Mandal CK, Ghorai PA, Rao YM, Das D, et al. Preoperative glycosylated hemoglobin: a risk factor for patients undergoing coronary artery bypass. Ann Thorac Surg. 2017;104:606-12.

E10. Nicolini F, Santarpino G, Gatti G, Reichart D, Onorati F, Faggian G, et al. Utility of glycated hemoglobin screening in patients undergoing elective coronary artery surgery: prospective, cohort study from the E-CABG registry. Int J Surg. 2018;53:354-9.

E11. Ramadan M, Abdelgawad A, Elshemy A, Sarawy E, Emad A, Mazen M, Abdel Aziz A. Impact of elevated glycosylated hemoglobin on hospital outcome and 1 year survival of primary isolated coronary artery bypass grafting patients. Egypt Heart J. 2018;70:113-8.

E12. Almogati JG, Ahmed EO. Glycated hemoglobin as a predictor of the length of hospital stay in patients following coronary bypass graft surgery in the Saudi population. Braz J Cardiovasc Surg. 2019;34:28-32.

E13. Robich MP, Iribarne A, Leavitt BJ, Malenka DJ, Quinn RD, Olmstead EM, et al. Northern New England Cardiovascular Disease Study Group. Intensity of glycemic control affects long-term survival after coronary artery bypass graft surgery. Ann Thorac Surg. 2019;107:477-84

E14. Kim HJ, Shim JK, Youn YN, Song JW, Lee H, Kwak YL. Influence of preoperative hemoglobin Alc on early outcomes in patients with diabetes mellitus undergoing off-pump coronary artery bypass surgery. J Thorac Cardiovasc Surg. 2020;159:568-76.

E15. Matsuura K, Imamaki M, Ishida A, Shimura H, Niitsuma Y, Miyazaki M. Offpump coronary artery bypass grafting for poorly controlled diabetic patients. Ann Thorac Cardiovasc Surg. 2009;15:18-22.

E16. Göksedef D, Ömeroğlu SN, Yalvaç ESD, Macit Bitargil M, İpek G. Is elevated $\mathrm{HbA} 1 \mathrm{c}$ a risk factor for infection after coronary artery bypass grafting surgery? Turk Gogus Kalp Dama. 2010;18:252-8.

E17. Tekumit H, Cenal AR, Polat A, Uzun K, Tataroglu C, Akinci E. Diagnostic value of hemoglobin A1c and fasting plasma glucose levels in coronary artery bypass grafting patients with undiagnosed diabetes mellitus. Ann Thorac Surg. 2010;89:1482-7.

E18. Strahan S, Harvey RM, Campbell-Lloyd A, Beller E, Mundy J, Shah P. Diabetic control and coronary artery bypass: effect on short-term outcomes. Asian Cardiovasc Thorac Ann. 2013;21:281-7.
E19. Surer S, Seren M, Saydam O, Bulut A, Kiziltepe U. The relationship between HbA1c \& atrial fibrillation after off-pump coronary artery bypass surgery in diabetic patients. Pak J Med Sci. 2016;32:59-64.

E20. Kocogulları CU, Kunt AT, Aksoy R, Duzyol C, Parlar H, Saskın H, et al. Hemoglobin A1c levels predicts acute kidney injury after coronary artery bypass surgery in non-diabetic patients. Braz J Cardiovasc Surg. 2017;32:83-9.

E21. Aydınlı B, Demir A, Özmen H, Vezir Ö, Ünal U, Özdemir M. Can pre-operative $\mathrm{HbA} 1 \mathrm{c}$ values in coronary surgery be a predictor of mortality? Turk J Anaesthesiol Reanim. 2018;46:184-90.

E22. Khan MR, Khan H, Wahab A, Chaudhary S, Munir A, Youssef J, et al. Effect of glycemic control on mortality and infections in patients undergoing coronary artery bypass grafting: a Genesee County experience. J Community Hosp Intern Med Perspect. 2019;9:74-9.

E23. Shoghli M, Jain R, Boroumand M, Ziaee S, Rafiee A, Pourgholi L, et al. Association of preoperative hemoglobin A1c with In-hospital mortality following valvular heart surgery. Braz J Cardiovasc Surg. 2020;35:654-9.

E24. Engoren M, Schwann TA, Arslanian-Engoren C, Maile M, Habib RH. U-shape association between hemoglobin A1c and late mortality in patients with hear failure after cardiac surgery. Am J Cardiol. 2013;111:1209-13.

E25. Nomikos I, Kyriazi M, Vamvakopoulou D, Sidiropoulos A, Apostolou A Kyritsaka A, et al. On the management of hyperglycaemia in critically ill patients undergoing surgery. J Clin Med Res. 2012;4:237-41.

E26. Kohnert KD, Heinke P, Vogt L, Salzsieder E. Utility of different glycemic control metrics for optimizing management of diabetes. World J Diabetes. 2015;6: 17-29.

E27. Selvin E, Steffes MW, Zhu H, Matsushita K, Wagenknecht L, Pankow J, et al Glycated hemoglobin, diabetes, and cardiovascular risk in nondiabetic adults. N Engl J Med. 2010;362:800-11.

E28. Kotagal M, Symons RG, Hirsch IB, Umpierrez GE, Dellinger EP, Farrokhi ET, et al; SCOAP-CERTAIN Collaborative. Perioperative hyperglycemia and risk of adverse events among patients with and without diabetes. Ann Surg. 2015 261:97-103.

E29. Giacco F, Brownlee M. Oxidative stress and diabetic complications. Circ Res 2010;107:1058-70

E30. Reichard P, Nilsson BY, Rosenqvist U. The effect of long-term intensified insulin treatment on the development of microvascular complications of diabetes mellitus. N Engl J Med. 1993;329:304-9.

E31. Zheng J, Cheng J, Wang T, Zhang Q, Xiao X. Does HbA1c level have clinical implications in diabetic patients undergoing coronary artery bypass grafting? A systematic review and meta-analysis. Int J Endocrinol. 2017;2017: 1537213.

E32. Wang J, Luo X, Jin X, Lv M, Li X, Dou J, et al. Effects of preoperative HbA1c levels on the postoperative outcomes of coronary artery disease surgical treatment in patients with diabetes mellitus and nondiabetic patients: a systematic review and meta-analysis. J Diabetes Res. 2020;2020:3547491.

E33. Gazzaruso C, Solerte SB, De Amici E, Mancini M, Pujia A, Fratino P, et al. As sociation of the metabolic syndrome and insulin resistance with silent myocardial ischemia in patients with type 2 diabetes mellitus. Am J Cardiol. 2006;97: 236-9.

E34. Lorusso R, Gelsomino S, Lucà F, De Cicco G, Billè G, Carella R, et al. Type 2 diabetes mellitus is associated with faster degeneration of bioprosthetic valve: results from a propensity score-matched Italian multicenter study. Circulation. 2012;125:604-14.

E35. Halkos ME, Kilgo P, Lattouf OM, Puskas JD, Cooper WA, Guyton RA, et al The effect of diabetes mellitus on in-hospital and long-term outcomes after heart valve operations. Ann Thorac Surg. 2010;90:124-30.

E36. International Diabetes Federation. International Diabetes Federation Diabetes Atlas. 7th ed. Brussels, Belgium: International Diabetes Federation; 2015.

E37. Roberts S, Barry E, Craig D, Airoldi M, Bevan G, Greenhalgh T. Preventing type 2 diabetes: systematic review of studies of cost-effectiveness of lifestyle programmes and metformin, with and without screening, for pre-diabetes. BMJ Open. 2017;7:e017184.

E38. Gazzaruso C, Coppola A, Luppi C, Giustina A, Solerte SB. Effect of different diabetes mellitus treatments on functional decline and death in elderly adults with diabetes mellitus. J Am Geriatr Soc. 2013;61:666-7. 

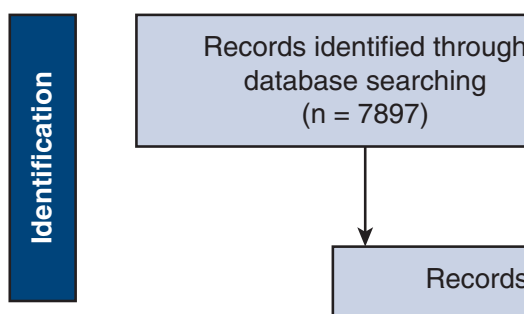
database searching $(n=7897)$

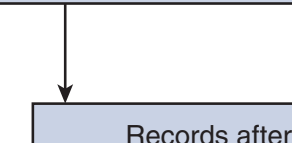

Records after duplicates removed

$$
(n=6549)
$$
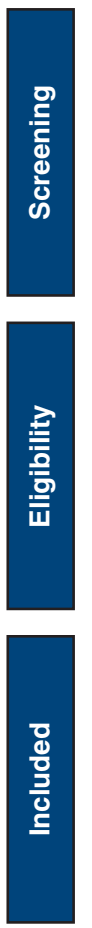
Studies included in $(n=30)$

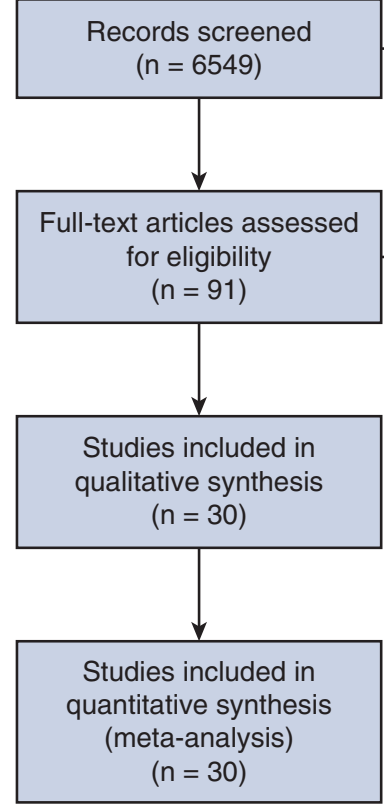

Additional records identified through other sources

$$
(n=0)
$$

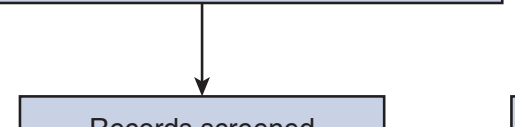

FIGURE E1. Preferred Reporting Items for Systematic Review and Meta-Analysis flow chart describing study selection process along with reasons for study exclusion. $H b A 1 c$, Glycosylated hemoglobin. 


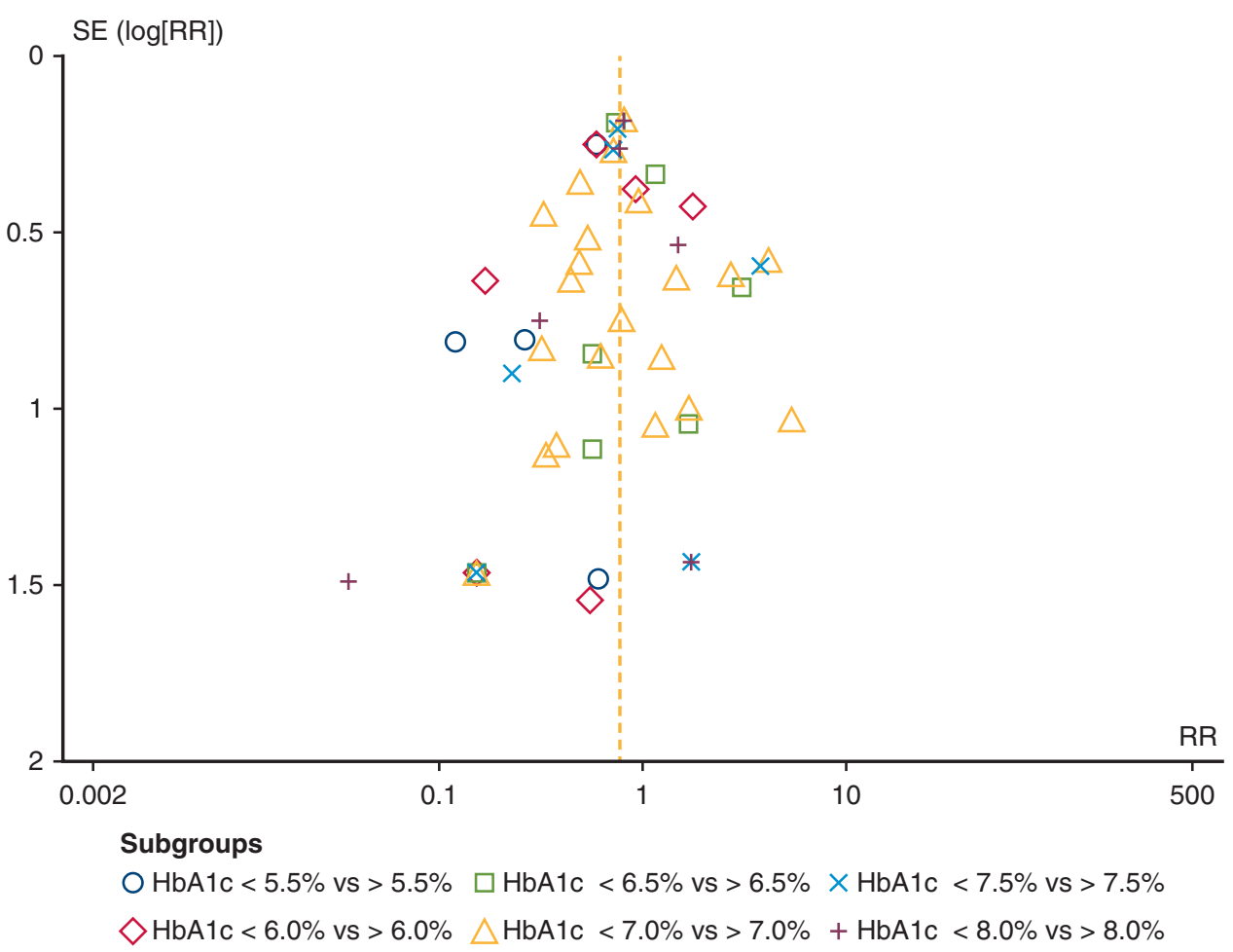

FIGURE E2. Publication bias analysis. Funnel plot. $S E$, Standard error; $R R$, risk ratio; HbAlc, glycosylated hemoglobin. 


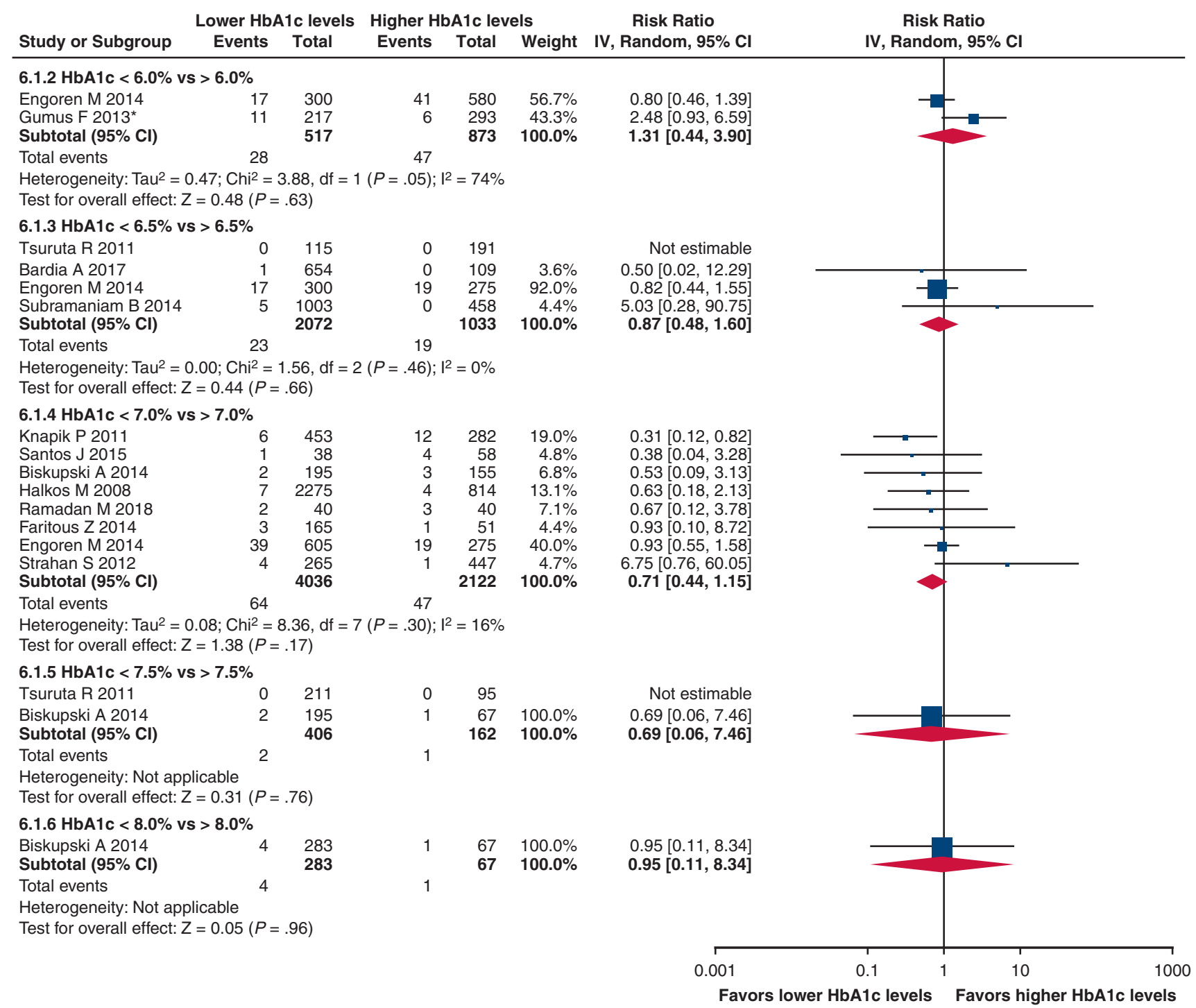

FIGURE E3. Meta-analysis of MI. Size of a square corresponds to statistical weight of a study; black diamonds are indicative of effect estimate. HbAlc, Glycosylated hemoglobin; $I V$, inverse variance; $C I$, confidence interval. 


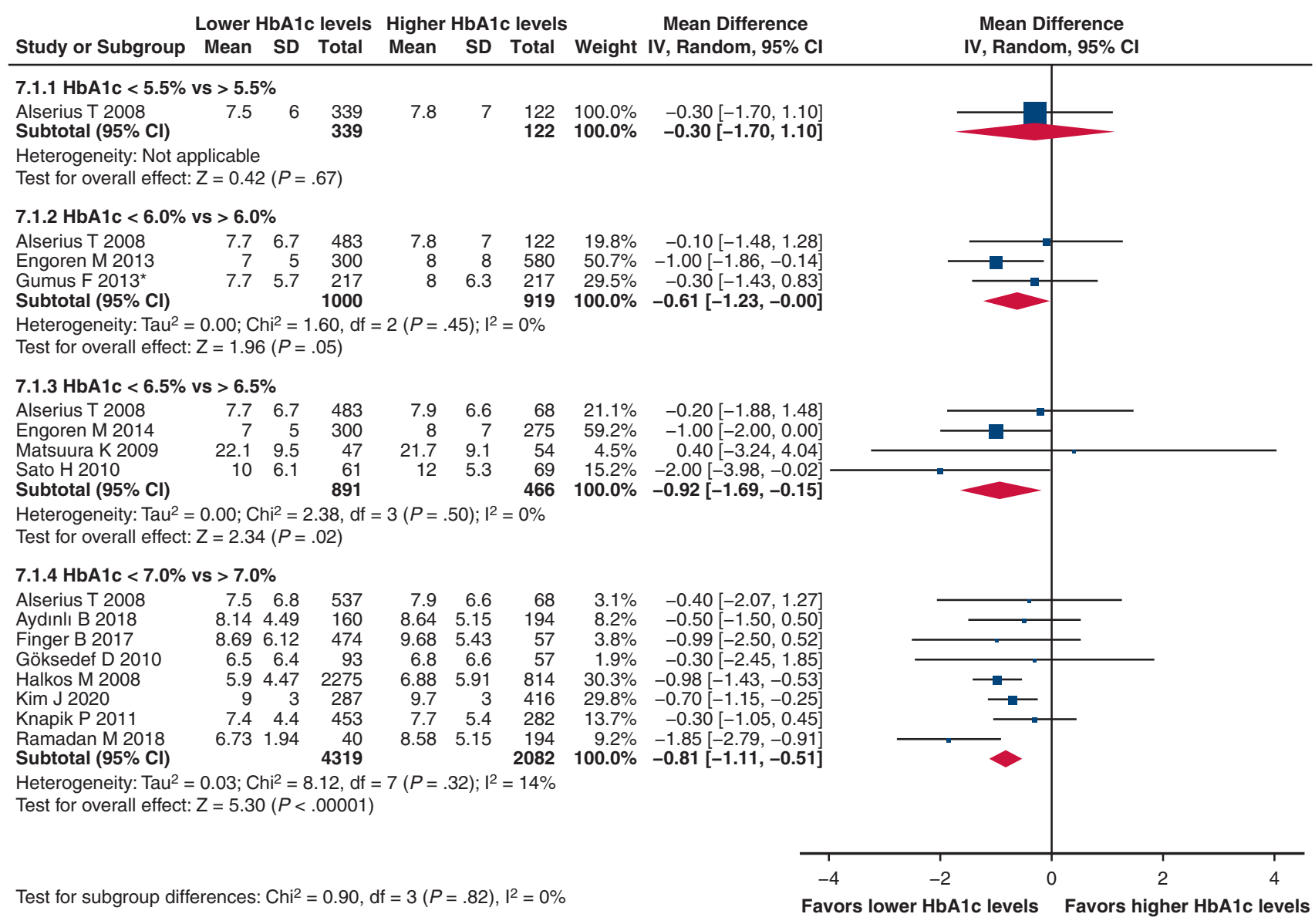

FIGURE E4. Meta-analysis of hospital length of stay. Size of a square corresponds to statistical weight of a study; black diamonds are indicative of effect estimate. $H b A l c$, Glycosylated hemoglobin; $S D$, standard deviation; IV, inverse variance; $C I$, confidence interval. 
TABLE E1. Patients' baseline characteristics

\begin{tabular}{|c|c|c|c|c|c|c|c|c|}
\hline $\begin{array}{c}\text { Author } \\
\text { (Ref) }\end{array}$ & $\begin{array}{c}\text { Year of } \\
\text { publication }\end{array}$ & $\begin{array}{l}\text { Patients } \\
\text { (n) }\end{array}$ & $\begin{array}{l}\text { Mean } \\
\text { age }(y)\end{array}$ & Male (n) & DM (n) & HbA1c thresholds & $\begin{array}{l}\text { Guidelines } \\
\text { used, year }\end{array}$ & $\begin{array}{l}\text { Type of cardiac } \\
\text { operations (n) }\end{array}$ \\
\hline Alserius $\mathrm{T}$ & 2008 & 605 & 65 & $478(79 \%)$ & $161(26.6 \%)$ & $\begin{array}{l}<5 \% \text { vs } 5 \%<6 \% \text { vs } \\
6 \%<7 \% \text { vs } \geq 7 \%\end{array}$ & Author choice & $\mathrm{CABG}=605(100 \%)$ \\
\hline Halkos M & 2008 & 3089 & 62.6 & $2243(72.6 \%)$ & $1240(40.1 \%)$ & $<7 \%$ vs $\geq 7 \%$ & ADA, $2005^{*}$ & $\mathrm{CABG}=3089(100 \%)$ \\
\hline Matsuura K & 2009 & 101 & 65.5 & $80(79.2 \%)$ & $101(100 \%)$ & $<6.5 \%$ vs $\geq 6.5 \%$ & Author choice & $\mathrm{CABG}=101(100 \%)$ \\
\hline Göksedef D & 2010 & 150 & 61.7 & $106(70.7 \%)$ & $53(35.3 \%)$ & $<7 \%$ vs $\geq 7 \%$ & ADA, $2005^{*}$ & $\mathrm{CABG}=150(100 \%)$ \\
\hline Sato $\mathrm{H}$ & 2010 & 130 & 66.9 & $91(70 \%)$ & $130(100 \%)$ & $<6.5 \%$ vs $\geq 6.5 \%$ & $\begin{array}{l}\text { IEC report, } \\
2009 \dagger\end{array}$ & $\begin{array}{c}\mathrm{CABG}=78(60 \%) \\
\text { valve }=24(18.5 \%) \\
\mathrm{CABG}+\mathrm{valve}=28 \\
(21.5 \%)\end{array}$ \\
\hline Tekumit H & 2010 & 166 & 60.8 & $104(62.6 \%)$ & $54(32.5 \%)$ & $<6.1 \%$ vs $\geq 6.1 \%$ & Author choice & $\mathrm{CABG}=166(100 \%)$ \\
\hline Knapik P & 2011 & 735 & 64.7 & $487(66.2 \%)$ & $735(100 \%)$ & $\leq 7 \%$ vs $>7 \%$ & ADA, $2005^{*}$ & $\mathrm{CABG}=735(100 \%)$ \\
\hline Tsuruta R & 2011 & 306 & 59.8 & $242(79.1 \%)$ & $306(100 \%)$ & $\begin{array}{c}<6.5 \% \text { vs } 6.5 \%<7.5 \% \\
\text { vs } \geq 7.5 \%\end{array}$ & Author choice & $\mathrm{CABG}=306(100 \%)$ \\
\hline Strahan S & 2012 & 712 & NA & NA & $712(100 \%)$ & $<7 \%$ vs $\geq 7 \%$ & UK PDS $\ddagger$ & $\mathrm{CABG}=712(100 \%)$ \\
\hline Gumus $\mathrm{F}$ & 2013 & 510 & 60.6 & $382(74.9 \%)$ & $205(40.2 \%)$ & $\leq 5.9 \%$ vs $>5.9 \%$ & Author choice & $\begin{array}{c}\mathrm{CABG}=491(96.3 \%) \\
\mathrm{ABG}+\text { valve }=19(3.7 \%)\end{array}$ \\
\hline Biskupski A & 2014 & 350 & 65.6 & $239(68.3 \%)$ & $350(100 \%)$ & $\begin{array}{c}<7 \% \text { vs } 7 \%<8 \% \text { vs }> \\
8 \%\end{array}$ & Author choice & $\begin{array}{c}\text { CABG }=267(76.3 \%) \\
\text { valve }=19(5.4 \%) \\
\text { CABG }+ \text { valve }=64 \\
(18.3 \%)\end{array}$ \\
\hline Engoren M & 2014 & 880 & 64.7 & $640(72.7 \%)$ & $415(47.1 \%)$ & $\begin{array}{c}<6 \% \text { vs } 6 \%<6.9 \% \text { vs } \\
\geq 7 \%\end{array}$ & Author choice & $\mathrm{CABG}=880(100 \%)$ \\
\hline Faritous Z & 2014 & 216 & 64 & $138(63.9 \%)$ & $76(35.2 \%)$ & $\leq 7 \%$ vs $>7 \%$ & Author choice & $\mathrm{CABG}=216(100 \%)$ \\
\hline $\begin{array}{l}\text { Subramaniam } \\
\text { B }\end{array}$ & 2014 & 1461 & 68 & $1,093(74.8 \%)$ & $562(38.5 \%)$ & $<6.5 \%$ vs $\geq 6.5 \%$ & Author choice & $\begin{array}{c}\text { CABG }=1083(74.1 \%) \\
\text { CABG }+ \text { valve }=378 \\
(25.9 \%)\end{array}$ \\
\hline Nyström T & 2015 & 764 & 57 & $425(55.6 \%)$ & $764(100 \%)$ & $\begin{array}{c}\leq 7 \% \text { vs } 7.1 \%<8 \% \text { vs } \\
8.1 \%<9 \% \text { vs } 9.1 \% \\
<10 \% \text { vs }>10 \%\end{array}$ & Author choice & $\mathrm{CABG}=764(100 \%)$ \\
\hline Santos J & 2015 & 96 & 63.6 & $79(82.3 \%)$ & $96(100 \%)$ & $\leq 7 \%$ vs $>7 \%$ & ADA, $2001 \S$ & $\mathrm{CABG}=96(100 \%)$ \\
\hline Kuhl J & 2016 & 6313 & 68.4 & $4834(76.6 \%)$ & $6313(100 \%)$ & $\begin{array}{c}\leq 7 \% \text { vs } 7.1 \%<8 \% \text { vs } \\
8.1 \%<9 \% \text { vs } 9.1 \% \\
<10 \% \text { vs }>10 \%\end{array}$ & Author choice & $\mathrm{CABG}=6313(100 \%)$ \\
\hline Surer $\mathrm{S}$ & 2016 & 72 & 63.2 & $40(55.5 \%)$ & $72(100 \%)$ & $\begin{array}{c}<5.5 \% \text { vs } 5.5 \%<8 \% \text { vs } \\
>8 \%\end{array}$ & Author choice & $\mathrm{CABG}=72(100 \%)$ \\
\hline Bardia A & 2017 & 763 & 67 & $418(54.8 \%)$ & $145(19 \%)$ & $<6.5 \%$ vs $\geq 6.5 \%$ & Author choice & Valve $=763(100 \%)$ \\
\hline Finger B & 2017 & 531 & 62.6 & $385(72.5 \%)$ & $182(34.3 \%)$ & $\leq 7 \%$ vs $>7 \%$ & ADA, 2015 & $\begin{array}{c}\mathrm{CABG}=269(50.6 \%) \\
\text { valve }=121(22.8 \%) \\
\mathrm{CABG}+\text { valve }=52 \\
(9.8 \%) ; \text { other }=89 \\
(16.8 \%)\end{array}$ \\
\hline Kocogullari C & 2017 & 202 & 61.6 & $162(80.2 \%)$ & $0(0 \%)$ & $<5.6 \%$ vs $\geq 5.6 \%$ & Author choice & $\mathrm{CABG}=202(100 \%)$ \\
\hline Narayan P & 2017 & 4678 & 58.8 & $4254(90.9 \%)$ & $3045(65.1 \%)$ & $<6.5 \%$ vs $\geq 6.5 \%$ & Author choice & $\mathrm{CABG}=4678(100 \%)$ \\
\hline Aydinli B & 2018 & 354 & 60.8 & $223(63 \%)$ & $354(100 \%)$ & $<7 \%$ vs $\geq 7 \%$ & Author choice & $\mathrm{CABG}=354(100 \%)$ \\
\hline Nicolini F & 2018 & 2606 & 67.5 & $2241(86 \%)$ & $942(36.1 \%)$ & $\begin{array}{c}<7 \% \text { vs } 7 \%<9 \% \text { vs }> \\
9 \%\end{array}$ & Author choice & $\mathrm{CABG}=2606(100 \%)$ \\
\hline Ramadan M & 2018 & 80 & 57.4 & $61(76.2 \%)$ & $80(100 \%)$ & $\leq 7 \%$ vs $>7 \%$ & ADA, 2006 $\|$ & $\mathrm{CABG}=80(100 \%)$ \\
\hline Almogati JG & 2019 & 305 & 59.1 & $250(82 \%)$ & $249(81.6 \%)$ & $<7 \%$ vs $\geq 7 \%$ & ADA, 2017 & $\mathrm{CABG}=305(100 \%)$ \\
\hline
\end{tabular}


TABLE E1. Continued

\begin{tabular}{|c|c|c|c|c|c|c|c|c|}
\hline $\begin{array}{c}\text { Author } \\
\text { (Ref) }\end{array}$ & $\begin{array}{c}\text { Year of } \\
\text { publication }\end{array}$ & $\begin{array}{c}\text { Patients } \\
\text { (n) }\end{array}$ & $\begin{array}{c}\text { Mean } \\
\text { age }(y)\end{array}$ & Male (n) & DM (n) & HbA1c thresholds & $\begin{array}{l}\text { Guidelines } \\
\text { used, year }\end{array}$ & $\begin{array}{l}\text { Type of cardiac } \\
\text { operations (n) }\end{array}$ \\
\hline Khan M & 2019 & 1133 & 65 & $780(68.8 \%)$ & $545(48.1 \%)$ & $\leq 7 \%$ vs $>7 \%$ & Author choice & $\mathrm{CABG}=1133(100 \%)$ \\
\hline Robich M & 2019 & 6415 & 65.6 & $4965(77.4 \%)$ & $2674(41.7 \%)$ & $\begin{array}{l}<5.7 \% \text { vs } 5.7 \%<6.4 \% \\
\text { vs } 6.5 \%<8 \% \text { vs }>8 \%\end{array}$ & ADA categories & $\mathrm{CABG}=6415(100 \%)$ \\
\hline Shoghli M & 2019 & 224 & 59.1 & $71(31.7 \%)$ & $224(100 \%)$ & $<7 \%$ vs $\geq 7 \%$ & ADA, 2014 & Valve $=224(100 \%)$ \\
\hline Kim J & 2020 & 703 & 65.8 & $499(71 \%)$ & $703(100 \%)$ & $<7 \%$ vs $\geq 7 \%$ & ADA, 2018\# & $\mathrm{CABG}=703(100 \%)$ \\
\hline Total & & 34,650 & $\begin{array}{c}63.2 \pm \\
3.2\end{array}$ & $26,010(76.6 \%)$ & $21,488(62 \%)$ & & & $\begin{array}{c}\text { CABG }=32,869 ; \\
\text { valve }=1151 ; \\
\text { CABG }+ \text { valve }=541 ; \\
\text { other }=89\end{array}$ \\
\hline
\end{tabular}

Data are shown as number (\%) or mean value \pm standard deviation. $D M$, Diabetes mellitus; $H b A l c$, glycosylated hemoglobin; $C A B G$, coronary artery bypass grafting; $A D A$, American Diabetes Association; IEC, International Expert Committee; NA, not available; UK PDS, United Kingdom Prospective Diabetes Study. *American Diabetes Association. Standards of medical care in diabetes. Diabetes Care. 2005;28(Suppl 1):4-36. †American Diabetes Association. Standards of medical care for patients with diabetes mellitus: Clinical practice recommendations 2001. Diabetes Care. 2001;24:(Suppl 1):S33-43. $\ddagger$ The ACE/ADA Task Force on Inpatient Diabetes. American College of Endocrinology and American Diabetes Association Consensus Statement on inpatient diabetes and glycemic control. Diabetes Care. 2006;29:1955-62. ${ }^{\circledR}$ American Diabetes Association. Standards of medical care in diabetes-2014. Diabetes Care. 2014;37(Suppl 1):S14-80. ||American Diabetes Association. 6. Glycemic Targets: Standards of Medical Care in Diabetes2018. Diabetes Care. 2018;41(Suppl 1):S55-S64. "2009 International Expert Committee report on the role of the A1C assay in the diagnosis of diabetes. Diabetes Care. 32:132734. \#UKPDS: Intensive blood-glucose control with sulphonylureas or insulin compared with conventional treatment and risk of complications in patients with type 2 diabetes (UKPDS 33). UK Prospective Diabetes Study (UKPDS) Group. Lancet. 1998;352:837-53. 
TABLE E2. Postoperative complications and outcomes

\begin{tabular}{|c|c|c|c|c|c|c|c|c|}
\hline Author (Ref) & $\begin{array}{c}\text { Early } \\
\text { mortality (n) }\end{array}$ & $\begin{array}{c}\text { Mean } \\
\text { follow-up }(y)^{*}\end{array}$ & $\begin{array}{c}\text { Late } \\
\text { mortality (n) }\end{array}$ & $\begin{array}{l}\text { Sternal wound } \\
\text { infection (n) }\end{array}$ & Stroke/TIA (n) & $\operatorname{AKI}(\mathbf{n})$ & MI (n) & $\begin{array}{c}\text { Length of } \\
\text { hospital } \\
\text { stay (d) }\end{array}$ \\
\hline Alserius $\mathrm{T}$ & $10(1.6 \%)$ & 3.5 & $33(5.4 \%)$ & $59(9.7 \%)$ & NA & NA & $86(14.2 \%)$ & 7.7 \\
\hline Halkos M & $31(1 \%)$ & NA & NA & $29(0.9 \%)$ & $53(1.7 \%)$ & $80(2.6 \%)$ & $11(0.4 \%)$ & 6.2 \\
\hline Matsuura K & 0 & 2.4 & 0 & $2(2 \%)$ & $1(1 \%)$ & $3(3 \%)$ & NA & 21.9 \\
\hline Göksedef D & $6(4 \%)$ & NA & NA & $2(1.3 \%)$ & NA & NA & NA & 6.6 \\
\hline Sato H & $6(4.6 \%)$ & NA & NA & $16(12.3 \%)$ & $3(2.3 \%)$ & $4(3 \%)$ & NA & 9.6 \\
\hline Tekumit H & $2(1.2 \%)$ & NA & NA & NA & NA & NA & NA & NA \\
\hline Knapik P & $15(2 \%)$ & NA & NA & $6(0.8 \%)$ & $15(2 \%)$ & $7(0.9 \%)$ & $18(2.4 \%)$ & 7.5 \\
\hline Tsuruta R & 0 & 3.6 & $19(6.2 \%)$ & $2(0.6 \%)$ & $2(0.6 \%)$ & $5(1.6 \%)$ & 0 & NA \\
\hline Strahan S & $4(0.6 \%)$ & NA & NA & NA & $5(0.7 \%)$ & $12(1.7 \%)$ & $5(0.7 \%)$ & NA \\
\hline Gumus F & $27(5.3 \%)$ & NA & NA & $6(1.2 \%)$ & $26(5.1 \%)$ & $39(7.6 \%)$ & $17(3.3)$ & 8.9 \\
\hline Biskupski A & $7(2 \%)$ & NA & NA & $10(2.8 \%)$ & $17(4.8 \%)$ & $11(3.1 \%)$ & $5(1.4 \%)$ & NA \\
\hline Engoren M & $19(2.1 \%)$ & $2.2 \dagger$ & $122 \dagger(12.4 \%)$ & $4(0.4 \%)$ & $14(1.5 \%)$ & $26(2.7 \%)$ & $58(6 \%)$ & 7.7 \\
\hline Faritous Z & $6(2.8 \%)$ & NA & NA & $12(5.5 \%)$ & NA & $9(4.2 \%)$ & $4(1.8 \%)$ & NA \\
\hline Subramaniam B & $42(2.9 \%)$ & NA & NA & $15(1 \%)$ & $19(1.3 \%)$ & $44(3 \%)$ & $5(0.3 \%)$ & NA \\
\hline Nyström T & $14(1.8 \%)$ & 4.7 & $179(23.4 \%)$ & NA & NA & NA & NA & NA \\
\hline Santos J & $5(5.2 \%)$ & NA & NA & $3(3.1 \%)$ & 0 & $6(6.2 \%)$ & $5(5.2 \%)$ & NA \\
\hline Kuhl J & $126(2 \%)$ & 5.5 & $1630(25.8 \%)$ & NA & NA & NA & NA & NA \\
\hline Surer $S$ & $3(4.2 \%)$ & NA & NA & NA & NA & NA & NA & NA \\
\hline Bardia A & $11(1.4 \%)$ & NA & NA & $9(1.2 \%)$ & $23(3 \%)$ & $25(3.3 \%)$ & $1(0.1 \%)$ & NA \\
\hline Finger B & $15(2.8 \%)$ & NA & NA & $7(1.3 \%)$ & $6(1.1 \%)$ & $72(13.5 \%)$ & NA & 8.8 \\
\hline Kocogullari C & $8(4 \%)$ & NA & NA & NA & NA & $19(9.4 \%)$ & NA & NA \\
\hline Narayan $\mathrm{P}$ & $169(3.6 \%)$ & NA & NA & $106(2.3 \%)$ & $117(2.5 \%)$ & $169(3.6 \%)$ & NA & NA \\
\hline Aydinli B & $28(7.9 \%)$ & NA & NA & NA & NA & NA & NA & 8.4 \\
\hline Nicolini F & $17(0.6 \%)$ & NA & NA & $177(6.8 \%)$ & $25(1 \%)$ & $549(21 \%)$ & NA & NA \\
\hline Ramadan M & $4(5 \%)$ & 1 & $5(6.2 \%)$ & $17(21.2 \%)$ & $2(2.5 \%)$ & $4(5 \%)$ & $5(6.2 \%)$ & 7.6 \\
\hline Almogati JG & $15(4.9 \%)$ & NA & NA & $12(3.9 \%)$ & $6(2 \%)$ & $17(5.6 \%)$ & NA & NA \\
\hline Khan M & $28(2.5 \%)$ & NA & NA & $12(1.1 \%)$ & NA & NA & NA & NA \\
\hline Robich M & $15(0.2 \%)$ & 2.6 & $946(14.7 \%)$ & $12(0.2 \%)$ & $6(0.1 \%)$ & $16(0.3 \%)$ & NA & NA \\
\hline Shoghli M & $13(5.8 \%)$ & NA & NA & NA & NA & NA & NA & 13.4 \\
\hline Kim J & $10(1.4 \%)$ & NA & NA & $33(4.7 \%)$ & $8(1.1 \%)$ & $29(4.1 \%)$ & NA & 9 \\
\hline Total & $656(1.9 \%)$ & $3.9 \pm 1.4$ & $2934(18.8 \%)$ & $551(2.1 \%)$ & $348(1.4 \%)$ & $1146(4.6 \%)$ & $220(2.2 \%)$ & $9.5 \pm 4.1$ \\
\hline
\end{tabular}


TABLE E3. Quality scoring for included papers using the Quality In Prognosis Studies tool

\begin{tabular}{|c|c|c|c|c|c|c|}
\hline Author & $\begin{array}{c}\text { Study } \\
\text { participation }\end{array}$ & $\begin{array}{c}\text { Study } \\
\text { attrition }\end{array}$ & $\begin{array}{c}\text { Prognostic factor } \\
\text { measurement }\end{array}$ & $\begin{array}{c}\text { Outcome } \\
\text { measurement }\end{array}$ & $\begin{array}{c}\text { Study } \\
\text { confounding }\end{array}$ & $\begin{array}{l}\text { Statistical analysis } \\
\text { and reporting }\end{array}$ \\
\hline Alserius $\mathrm{T}$ & low & low & low & low & moderate & low \\
\hline Biskupski A & low & low & low & low & moderate & moderate \\
\hline Faritous Z & low & low & low & low & moderate & low \\
\hline Finger B & low & low & low & low & moderate & low \\
\hline Gumus F & low & low & low & low & low & low \\
\hline Halkos M & moderate & low & low & moderate & low & low \\
\hline Kim J & low & low & low & low & moderate & low \\
\hline Knapik P & low & low & low & low & moderate & low \\
\hline Kuhl J & moderate & low & low & low & moderate & low \\
\hline Narayan P & moderate & low & low & low & moderate & low \\
\hline Nicolini F & low & low & low & low & moderate & low \\
\hline Nyström T & low & low & low & low & moderate & low \\
\hline Ramadan M & moderate & low & low & low & high & moderate \\
\hline Robich MP & low & low & moderate & moderate & moderate & low \\
\hline Santos J & moderate & low & low & low & moderate & low \\
\hline Sato H & low & low & moderate & moderate & moderate & low \\
\hline Subramaniam B & moderate & low & low & low & high & moderate \\
\hline Bardia A & low & moderate & low & low & low & low \\
\hline Tsuruta R & moderate & low & low & moderate & low & low \\
\hline Engoren $\mathrm{M}$ & lode & low & low & low & moderate & moderate \\
\hline Almogati JG & low & moderate & low & low & high & moderate \\
\hline Matsuura K & low & low & low & low & low & low \\
\hline Göksedef D & moderate & low & moderate & moderate & moderate & moderate \\
\hline Tekumit H & moderate & low & low & low & low & low \\
\hline Strahan S & low & low & low & moderate & high & low \\
\hline Surer $S$ & low & low & low & moderate & low & low \\
\hline Kocogullari C & low & low & low & low & low & low \\
\hline Aydinli B & low & low & low & low & low & low \\
\hline Khan M & low & low & low & low & low & low \\
\hline Shoghli M & moderate & moderate & moderate & moderate & moderate & low \\
\hline
\end{tabular}

Review authors' judgments about each risk of bias item for each included study. 
TABLE E4. Meta-regression of primary end point against baseline variables

\begin{tabular}{|c|c|c|c|c|c|c|}
\hline & \multicolumn{2}{|c|}{ Age (mean) } & \multicolumn{2}{|c|}{ Male (\%) } & \multicolumn{2}{|c|}{ DM $(\%)$} \\
\hline & $\beta$-coefficient & $P$ & $\beta$-coefficient & $P$ & $\beta$-coefficient & $P$ \\
\hline \multicolumn{7}{|l|}{ Early mortality } \\
\hline $\mathrm{HbA} 1 \mathrm{c}<5.5 \%$ vs $>5.5 \%$ & 0.105 & .724 & -3.657 & .610 & 1.459 & .388 \\
\hline $\mathrm{HbA} 1 \mathrm{c}<6.0 \%$ vs $>6.0 \%$ & -0.117 & .558 & -4.317 & .351 & -1.134 & 638 \\
\hline HbA $1 \mathrm{c}<6.5 \%$ vs $>6.5 \%$ & 0.032 & .473 & -1.685 & .243 & -1.112 & .136 \\
\hline $\mathrm{HbA} 1 \mathrm{c}<7.0 \%$ vs $>7.0 \%$ & 0.016 & .745 & 0.537 & .708 & -0.421 & .434 \\
\hline $\mathrm{HbA} 1 \mathrm{c}<7.5 \%$ vs $>7.5 \%$ & -0.129 & .074 & -3.191 & .340 & -0.173 & .914 \\
\hline $\mathrm{HbA} 1 \mathrm{c}<8.0 \%$ vs $>8.0 \%$ & -0.040 & .563 & 0.714 & .814 & -0.495 & 677 \\
\hline
\end{tabular}

